\title{
Evaluation of the Incidence, Severity and Forage Nutritive Value of Common Weed Species in Missouri Pastures
}

\author{
A Thesis \\ Presented to \\ The Faculty of the Graduate School \\ At the University of Missouri-Columbia \\ In Partial Fulfillment \\ Of the Requirements for the Degree \\ Master of Science \\ By \\ Zachary Lee Trower \\ Dr. Kevin Bradley, Thesis Supervisor
}

June 2017 
The undersigned, appointed by the dean of the Graduate School, have examined the Thesis entitled

\title{
Evaluation of the Incidence, Severity and Forage Nutritive Value of Common Weed Species in Missouri Pastures
}

\author{
Presented by Zachary Lee Trower, \\ A candidate for the degree of \\ Master of Science \\ And hereby certify that, in their opinion, it is worthy of acceptance.
}

Dr. Kevin W. Bradley

Dr. Craig A. Roberts

Dr. Allison M. Meyer 


\section{ACKNOWLEDGEMENTS}

There have been many people that have made the journey of getting my master's degree possible. First and foremost, I would like to thank my advisor, Dr. Kevin Bradley, for bringing me on as a graduate student. You took a chance on me even though I had not-so-good grades coming out of undergraduate, but you also heard that I had experience in field research and was a "smart-kid" (you're probably still questioning that one). The past two years has truly been a great experience. I feel honored to have been able to study and be mentored by someone who is so passionate and knowledgeable about weed science. Thank you!

I would also like to recognize Dr. Mandy Bish for all of your help throughout grad school. I appreciate everything you have done for not only myself, but all of the graduate students. I'm sure you will be able to get more work done without me coming in to annoy you when I got stuck on problems or was just in need of some advice. I would also like to thank Meghan Biggs for all of the time you spent with my projects and all of the time you give to the graduate students. Hopefully, you won't have to go out and survey any more pastures. Alex Long and David Kleinsorge, thank you for all your time helping the program get field work done and making sure everything kept moving. Fellow graduate students Jaime Farmer, Blake Barlow, Eric Oseland, Derek Whalen, Shea Farrell, Brian Dintelmann, and Gatlin Bunton: you have all made this trip fun and enjoyable and were always willing to jump in and help when it was needed.

Undergraduate workers Austin Straatmann, Drake Gleason, Wyatt Coffman, Blake Kasten, and Jesse Kleinheider: thank you for always making work fun and enjoyable and 
working in the dusty grinding rooms and forage lab to help me get my projects done. Thank you committee members Dr. Craig Roberts and Dr. Allison Meyer for taking time to meet and give me advice along the way during my forage quality project.

I would also like to thank my family and friends. Mom and Dad, you two supported me from the very notion of getting my master's degree, through the tough times during, and pushing me through to the finish. You two are always there to answer any question about crops, cows, and research, and I truly appreciate it. I am truly blessed to have two parents that have supported me through every endeavor I have gone through, and for that I am truly grateful.

Lastly, but most importantly, I have to give a lot of credit and thanks to my future wife, Gina. You moved 500+ miles to a new state, and stayed positive and supportive through the whole process. You helped and supported me with every aspect of grad school, from getting up at 2 a.m. to go count weeds in pastures in southern Missouri, to bringing me enchiladas when I spent late nights writing in the office. You went far above and beyond anything I could have ever asked you to do, and words can't describe how much I appreciate all that you have done and do for me every day. We have many great memories in many places, and I can't wait to spend a lifetime creating thousands more!

For everyone who has helped with this journey, thank you! 


\section{TABLE OF CONTENTS}

Acknowledgements ............................................................................................................. ii

List of Tables ...................................................................................................................

List of Figures......................................................................................................................................... vi

CHAPTER I: Literature Review.................................................................................. 1

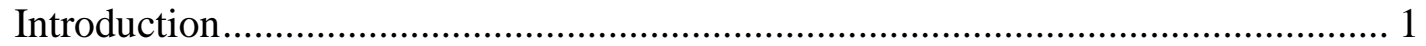



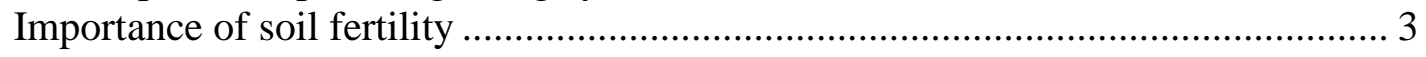

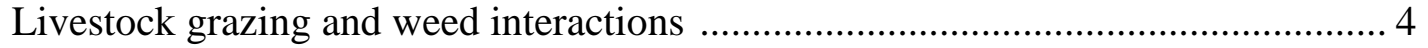

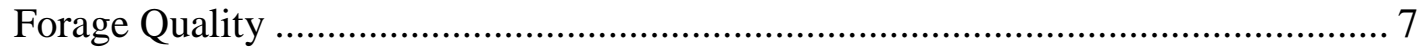

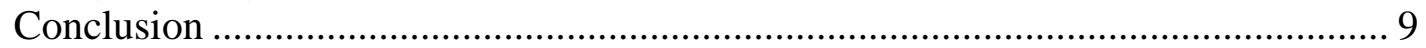

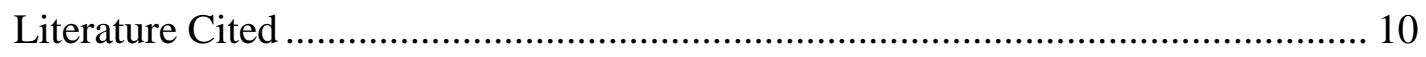

CHAPTER II: Relationships between Weed Incidence, Soil Fertility and pH, and Forage Parameters in Missouri Pastures............................................................................... 13

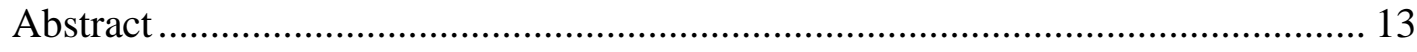

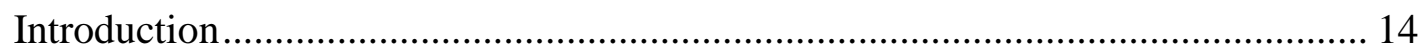

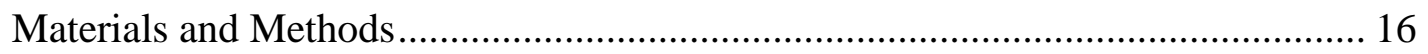

Results and Discussion ................................................................................. 19

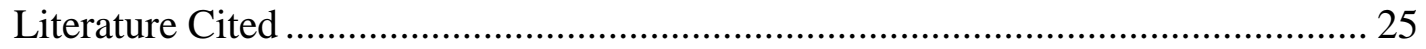

CHAPTER III: Seasonal Variation in Forage Nutritive Value of Common Pasture Weed Species in Missouri Pastures .......................................................................................... 46

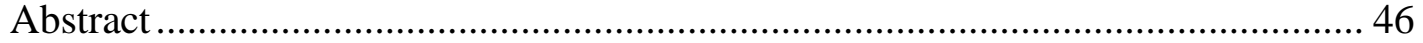

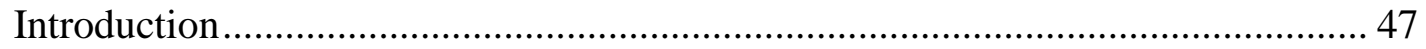



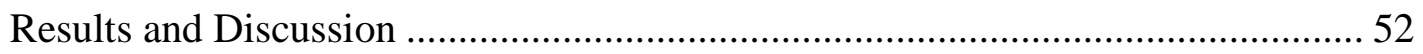






\section{Chapter II:}

2.1 Site characteristics for each pasture location surveyed in 2015 and 2016.

2.2 First 3 parameters of respective regression trees and their effect on weed density.

\section{Chapter III:}

3.1 Site characteristics for collection locations in 2015 and 2016. .61

3.2 Near-infrared reflectance spectroscopy calibration and validation statistics for CP and IVTD for 2015-2016 data. ..........................................................................63

3.3 Daily influence on nutritional values of selected weed species from emergence to maturity.

3.4 Comparisons in crude protein content between selected weed species and the respective pure forage sample at each collection timing throughout the season. .66

3.5 Comparisons in in vitro true digestibility content between selected weed species and the respective pure forage sample at each collection timing throughout the season. 
Figure

\section{LIST OF FIGURES}

\section{Chapter II:}

2.1 Location of pastures surveyed in Missouri. Gold stars represent the 24 locations surveyed in 2015, while red stars mark the 19 locations surveyed in 2016.

2.2 Regression tree predicting the average weed density per $20 \mathrm{~m}^{2}$ in the spring (April-May) timeframe $\left(\mathrm{R}^{2}=0.33\right)$.

2.3 Regression tree predicting the average weed density per $20 \mathrm{~m}^{2}$ in the summer (June-July) timeframe $\left(\mathrm{R}^{2}=0.46\right)$.

2.4 Regression tree predicting the average weed density per $20 \mathrm{~m}^{2}$ in the fall (AugustSeptember) timeframe $\left(\mathrm{R}^{2}=0.41\right)$.

2.5 Regression tree predicting the average annual broadleaf density per $20 \mathrm{~m}^{2}$ in the spring (April-May) timeframe $\left(\mathrm{R}^{2}=0.48\right)$.

2.6 Regression tree predicting the average annual broadleaf density per $20 \mathrm{~m}^{2}$ in the summer (June-July) timeframe $\left(\mathrm{R}^{2}=0.61\right)$.

2.7 Regression tree predicting the average annual broadleaf density per $20 \mathrm{~m}^{2}$ in the fall (August-September) timeframe $\left(\mathrm{R}^{2}=0.61\right)$.

2.8 Regression tree predicting the average perennial broadleaf density per $20 \mathrm{~m}^{2}$ in the spring (April-May) timeframe $\left(\mathrm{R}^{2}=0.40\right)$.

2.9 Regression tree predicting the average perennial broadleaf density per $20 \mathrm{~m}^{2}$ in the summer (June-July) timeframe $\left(\mathrm{R}^{2}=0.59\right)$.

2.10 Regression tree predicting the average perennial broadleaf density per $20 \mathrm{~m}^{2}$ in the fall (August-September) timeframe $\left(\mathrm{R}^{2}=0.53\right)$.

2.11 Regression tree predicting the average annual grass density per $20 \mathrm{~m}^{2}$ in the summer (June-July) timeframe $\left(\mathrm{R}^{2}=0.54\right)$.

2.12 Regression tree predicting the average annual grass density per $20 \mathrm{~m}^{2}$ in the fall (August-September) timeframe $\left(\mathrm{R}^{2}=0.61\right)$.

2.13 Range in soil phosphorus (Pppm), potassium (Kppm) and soil $\mathrm{pH}$ for all soil samples taken in the 2015-2016 pasture survey. 


\section{Chapter I}

Literature review

\section{Introduction}

Grassland pasture and rangeland make up an estimated 214 million ha, or $29.2 \%$, of the total land area of the United States and approximately 2.83 million ha of land in Missouri (USDA ERS 2012). Missouri ranks 3rd in the nation in beef cattle production, with approximately 1.9 million head of beef cows (NASS 2015). The predominant source of nutrition for these beef cattle is forage from pastures.

In Missouri, and throughout much of the lower midwest, tall fescue (Lolium arundinacea Shreb.) is the predominant forage grass found in pastures (Glenn et al. 1981). Tall fescue is a deep-rooted perennial that can serve as a long-term forage source and is also used for erosion control (Cherney and Johnson 1993). Across Missouri, most pastures are a mix of tall fescue and other legume and grass species, which allows for a higher quality forage compared to a single species system (Gerrish and Roberts 1999). Common legume and grass mixes include tall fescue, white clover (Trifolium repens L.), red clover (Trifolium pretense L.), orchardgrass (Dactylis glomerata L.), and Kentucky bluegrass (Poa pratensis L.) (Roberts and Wheaton 1993). Mixed tall fescue and legume pastures can be a very productive and yet inexpensive source of nutrition.

Unfortunately, weed management in mixed-legume systems can be difficult as selective herbicides that are targeted towards broadleaf weeds will also eliminate any desirable legumes (Green and Martin 1998). Because of this, many producers desire an alternative method of weed control other than an herbicide application. One potential 
source of cultural weed control is through optimum maintenance of soil nutrient and $\mathrm{pH}$ levels.

\section{Weed species impact on grazing systems}

Annual, biennial, and perennial weed species are the number one pest found in Missouri pastures as well as pastures across the United States. Weeds compete for space, nutrients, moisture, and light that is needed for healthy forage growth, ultimately lowering forage yield and quality (Green et al. 2006; Rosenbaum et al. 2011). It has been estimated that weed infestations cause 2 billion dollars in loss annually in the United States (Bovey 1987). A large portion of this loss is due to reduced forage production as a result of weed infestations. For example, Canada thistle (Cirsium arvense L.) densities of 20 shoots per $\mathrm{m}^{2}$ were shown to reduce overall pasture yield by as much as $868 \mathrm{~kg} / \mathrm{ha}$ (Grekul and Bork 2004). Similarly, nodding thistle (Carduus nutans L.) densities of 0.1 plant per $\mathrm{m}^{2}$ have been shown to reduce forage production by 8 percent (Thompson et al. 1987).

Another way weeds can be detrimental to forage production and grazing environments is through the production of poisonous toxins. Perilla mint (Perilla frutescens L.), also known as beefsteak plant, is a common pasture weed found in Missouri that can cause death in cattle. The amount of plant material to cause death ranged from 2.3 to $15.5 \mathrm{~kg}$ of green, seed-stage plant material (Kerr et al. 1986). Specific ketones within the plant's tissues can cause acute respiratory distress syndrome which often proves to be fatal to cattle that have ingested it (Steckel and Rhodes 2007). Poison hemlock (Conium maculatum L.) can also be lethal to cattle at ranges of 2 to 6 grams of plant material per $.45 \mathrm{~kg}$ of body weight (Panter et al. 1988). 
High nitrate levels in forages and weeds can be another source of cattle poisoning. High nitrate levels in ingested plants can be absorbed into the bloodstream of the animal, causing abortion, breeding problems, lower milk production, and death of the livestock (Hancock 2010). Redroot pigweed (Amaranthus retroflexus L.) and horsenettle (Solanum carolinense L.) with nitrate levels of 18.4 and $14.4 \mathrm{~g} \mathrm{~kg}^{-1}$, respectively, have been shown to contain toxic levels of nitrates (Carlisle et al. 1980).

Weeds can also be classified as noxious within a given state meaning they must be controlled by the farmer or agency who owns the land on which they occur. Canada thistle and multiflora rose (Rosa multiflora Thunb.) are problematic pasture weeds that are also deemed noxious by the state of Missouri (USDA NRCS 2016). In addition, musk thistle, field bindweed (Convolvulus arvensis L.), common teasel (Dipsacus fullonum L), purple loosestrife (Lythrum salicaria L.), and johnsongrass (Sorghum halepense L.) are all deemed noxious in Missouri, and many of these can occur in pasture settings. Most of these species are difficult to control and can result in fines to landowners who fail to attempt control methods (Anonymous 2016).

\section{Importance of soil fertility}

Proper soil $\mathrm{pH}$ and fertility levels are important cultural practices used to maintain adequate forage stands and yield in pasture environments (Angima 2007). An optimum soil $\mathrm{pH}$ of 6 to 7 is recommended for tall fescue and white clover; two of the most common forages found in Missouri pastures (Henning and Wheaton 1993). Phosphorus is also an important nutrient for establishment and maintenance of tall fescue pastures by promoting root development and plant establishment (Henning et al. 1993). 
When soil fertility and $\mathrm{pH}$ levels are low, some weed species may be more likely to germinate and grow in place of the more favorable forage (Green and Martin 1998). In one study conducted in New Zealand, there were correlations between specific soil fertility components and broadleaf dock (Rumex obtusifolius) and Canada thistle density. Broadleaf dock density had shown significant correlations to soil $\mathrm{pH}$, potassium, magnesium, and manganese with Pearson correlation coefficients of .38, .37, -.31, -.33, respectively. Canada thistle density had significant correlations to soil $\mathrm{pH}$ and sulfur with Pearson correlation coefficients of .5 and -.26, respectively (Harrington et al. 2014). Even though the fertility correlations did not explain all of the density relationships, it did give some insight to why broadleaf dock and Canada thistle densities were higher in some areas compared to others. Peters and Lowance (1974) also showed that broomsedge (Andropogon virginicus L.) was eliminated within a 4 year time period through the addition of nitrogen, potassium, and phosphorus fertilizer which increased competition of the forage (Peters and Lowance 1974). A study from Kok et al. (1986) also showed that musk thistle seed production was reduced by 89 to $97 \%$ through increased competition with tall fescue (Kok et al. 1986).

\section{Livestock grazing and weed interactions}

The most common grazing systems implemented in the United States are continuous, rotational, and ultra-high stock density, or mob grazing. A continuous grazing system is a system were cattle graze a pasture for an extended amount of time with no or very little rest to the plants (Smith et al. 2017b). Advantages of this system include lower setup cost and less required management. There are many disadvantages to 
this system including a high likelihood of weed invasion, poor manure distribution, poor legume persistence, and less beef production per acre (Pfost et al. 2000).

Because of the disadvantages associated with the continuous grazing systems, many producers have moved to a managed system called rotational grazing. A rotational grazing system consists of a large pasture divided into smaller paddocks, allowing cattle to be moved from one paddock to another (Smith et al. 2017b). This system gives the producer the ability to more effectively manage pasture and cattle growth. The desirable forages have periods of rest to regrow and build biomass before cattle are returned to the paddock. This allows the pasture and the cattle to be more productive. Additionally, this allows for fall stockpiling of forage that is not attainable with a continuous grazing system. Some disadvantages of this system are increased supply and labor requirements, difficulty in legume maintenance, and manure distribution may still be uneven (Pfost et al. 2000).

An old grazing strategy that has seen more increased testing and implementation is ultra-high stock density grazing, also referred to more commonly as mob grazing. Mob grazing systems involve stocking a large amount of cattle on a small area for a short duration of time (Smith et al. 2017a). These cattle are usually only allowed on an area for 1 to 2 days depending on herd density, but then the grazed area is rested for a longer interval (60-90 days). Even though this system has not been extensively researched, supporters cite improvements in soil quality, reductions in grazing selectivity, and extended grazing seasons. There is considerably more labor required for this type of system as daily cattle and fence movement is required and this systems may be difficult to accomplish for producers with off-farm careers (Anonymous 2017). 
Regardless of the grazing system implemented, uneven grazing strategies can lead to increased weed growth due to reduced forage competition (Blackburn 1984). Increases in weed incidence can cause cattle to avoid certain parts of pastures, resulting in less overall forage use. A study by Sather et al. (2013) found that cattle distribution was 1.3 to 5 times greater in herbicide-treated portions of pastures compared to nontreated portions when cattle were given a choice (Sather et al. 2013). Cattle often determine which weeds to graze or avoid based on palatability. Palatability is defined as the selection or proportional choice by animals among two or more forage parameters (Marten 1978). For example, Bergen et al. (1990) showed that dandelion (Taraxacum officinale) was grazed as readily as grass, and even in one instance was favored over grass forage (Bergen et al. 1990). This was likely due to palatability and high crude protein content (Bergen et al. 1990). Marten et al. (1987) compared 8 perennial weeds to alfalfa (Medicago sativa L.) and smooth bromegrass (Bromus inermis Leyss.), and found that Canada thistle, hoary alyssum (Berteroa incana L.), swamp smartweed (Persicaria hydropiperoides Michx.), Jerusalem artichoke (Helianthus tuberosus L.), curly dock (Rumex crispus L.), and perennial sowthistle (Sonchus arvensis 1.) have similar crude protein and in vitro digestible dry matter levels as alfalfa, but they may reduce forage feeding value in a pasture setting due to their unpalatability from spines or bitter taste (Marten et al. 1987). Additionally, Marten and Andersen (1975) reported that 6 of 12 weeds in their study were as palatable to sheep as oats (Marten and Andersen 1975).

Even if a weed is unpalatable to livestock, in some cases livestock can essentially be forced to eat the weeds through mob grazing strategies. Canada thistle was utilized by cattle in 1 of 3 locations compared to rotational grazing strategies (Gurda et al. 2014). 
Even though this is a relatively old grazing strategy, this example might be considered as a weed control tactic.

\section{Forage Quality}

Forage quality is the potential that a forage has to provide a desired animal response (Ball et al. 2001). The factors that comprise forage quality are palatability, intake, digestibility, and nutrient content. The main factor that effects forage quality is stage of maturity of the plant, but soil fertility, environment, and variety play important roles in determining overall forage quality as well. Forage quality is expressed through several values, including crude protein (CP), neutral detergent fiber (NDF), acid detergent fiber (ADF), and relative feed value (RFV).

Crude protein is an estimate of the protein of a forage sample, which is 6.25 times the nitrogen content (Ball et al., 2001). Growing livestock require a forage with a crude protein level of 16 to $18 \%$ until they reach $50 \%$ of their mature weight, then the requirement lowers to $12 \%$ (Ball et al., 2001). Crude protein of many grass species is around $12 \%$, while legumes typically have much higher levels. Through fertilization with nitrogen, crude protein of tall fescue can be comparable to that of legumes (Ball et al., 2001).

Neutral detergent fiber (NDF) is a measurement of the total cell wall constituents including hemicellulose, cellulose, and lignin. NDF is used as a predictor of the potential for forage intake. Acid detergent fiber (ADF) is a measurement of cellulose and lignin, two forage constituents that do not dissolve in an acid detergent solution. ADF is related to the digestibility of the forage sample and as ADF values increase, the digestibility of 
the forage decreases (Ball et al., 2001). Quality legume and grass species have ADF values ranging from 20 to 35 and 30 to $45 \%$, respectively (Cole 2017). Relative feed value (RFV) is a calculation that uses ADF and NDF values to calculate digestible dry matter and dry matter intake, respectively.

More recently, RFV has been replaced with relative forage quality (RFQ), which takes more factors into consideration because RFV tends to discriminate against grasses (Undersander 2007). RFQ uses total digestible nutrients and dry matter intake for its calculation, making it more accurate for determining the actual quality of the forage. The ultimate test for the quality of a forage though is animal performance (Ball et al. 2001).

Even though forage analysis and forage quality are terms used to compare different forage cultivars and forage mixtures, it also can be used to determine how a weed species compares to the quality of a forage. A study of the forage nutritive value of 12 common annual weed species revealed that redroot pigweed, common lambsquarters (Chenopodium album L.), and common ragweed (Ambrosia artemisiifolia L.) had similar levels of $\mathrm{CP}, \mathrm{ADF}$, and in vitro digestible dry matter (IVDDM) as alfalfa (Marten and Andersen 1975). When redroot pigweed, common lambsquarters, common ragweed, Pennsylvania smartweed (Polygonum pensylvanicum L.), yellow foxtail (Setaria pumila (Poir.) Roemer \& J.A. Schultes), giant foxtail (Setaria faberi Herrm.), and barnyardgrass (Echinochla crus-galli L.) samples were combined in a mixture and compared to alfalfa, the IVDDM was not statistically different between the two comparisons. Common cocklebur (Xanthium strumarium), a common Missouri pasture weed, was shown to have an average $\mathrm{CP}$ content of $240 \mathrm{~g} \mathrm{~kg}^{-1}$, which is comparable to many high value legumes, but is unpalatable to livestock and shown to be completely rejected by sheep. Yellow 
foxtail was shown to have palatability comparable to oats, but the $\mathrm{CP}$ levels were much lower than other broadleaf weed and legume species (Marten and Andersen 1975). A study by Rosenbaum et al. (2011) showed that CP content of the total harvested forage decreased by 0.2 and $0.4 \mathrm{~g} \mathrm{~kg}^{-1}$ with each additional increase in common ragweed or common cocklebur density per $\mathrm{m}^{-2}$ (Rosenbaum et al. 2011). These examples suggest that weeds vary greatly in CP concentration across monocot and dicot species, and can potentially have substantial effects on forage quality of the entire pasture environment. However, there has been little research conducted on the seasonal changes in forage quality of common pasture weeds found in Missouri.

\section{Conclusion}

In summary, many factors can influence the emergence and density of weeds in a pasture setting, and weeds are the most significant pests encountered in grazing systems nationwide. Improper soil nutrient levels and grazing techniques can increase the density and variety of weed species. As weed infestations increase, forage productivity declines and this can result in reductions in cattle weight gain and farmer revenue.

Currently, there is very little research on the interaction between soil properties and weed incidence and severity in pastures. Additionally, there is little data that shows the seasonal variation in forage quality of common weeds encountered in mixed tall fescue and legume pastures. Therefore, the objectives of this research are to: 1) determine the effects of soil nutrient, soil $\mathrm{pH}$, and other grazing and forage system components on weed incidence and severity in tall fescue pastures and, 2) to examine the seasonal variation in forage nutritive value of common pasture weed species encountered in mixed tall fescue and legume pastures in Missouri. 


\section{Literature Cited:}

Angima S (2007) Fertilizing For Hay Production. Oregon State University Extension Service Vol. II No. 1.

Anonymous (2016) Noxious Weed Control. Missouri Department of Agriculture http://agriculture.mo.gov/plants/ipm/noxiousweeds.php. Accessed February 19, 2017

Anonymous (2017) Livestock Grazing Home Study Course. State College, PA. Online http://extension.psu.edu/courses/livestock-grazing. Accessed February 20, 2017

Ball DM, Collins M, Lacefield GD, Martin NP, Mertens DA, Olson KE, Putnam DH, Undersander DJ, Wolf M (2001) Understanding forage quality. American Farm Bureau Federation Publication 1-01, Park Ridge, Illinois

Bergen P, Moyer JR, Kozub GC (1990) Dandelion (Taraxacum officinale) use by cattle grazing on irrigated pastures. Weed Technol 4:258-263

Blackburn WH (1984) Impacts of grazing intensity and specialized grazing systems on watershed characteristics and responses. Developing Stratagies for Rangeland Management. Nat. Res. Council; Nat. Acad. Sci., Westview Press, Boulder, Colorado.

Bovey RW (1987) Weed control problems, Approaches, and Opportunities in Rangeland. Weed Sci. 3;57-91

Carlisle RJ, Watson VH, Cole AW (1980) Canopy and Chemistry of Pasture Weeds. Weed Sci 28:139-141

Cole E (2017) Understanding forage test. http://extension.missouri.edu/capegirardeau/documents/Understanding\%20Forage\%2 OTest.pdf. Accessed Febuary 19, 2017

USDA ERS (2012) United States State Fact Sheet. Economic Research Service.

Glenn S, Glenn B, Rieck CE, Ely DG, Bush LP (1981) Chemical quality, in vitro cellulose digestion, and yield of tall fescue forage affected by mefluidide. J. Agric. Food Chem. 29:1158-1161

Green JD, Martin JR (1998) Weed Management in Grass Pastures, Hayfields, and Fencerows. University of Kentucky Extension Service AGR-112.

Green JD, Witt WW, Martin JR (2006) Weed Management in Grass Pastures, Hayfields, and Other Farmstead Sites. University of Kentucky Extension Service AGR-172.

Grekul CW, Bork EW (2004) Herbage Yield Losses in Perennial Pasture Due to Canada Thistle (Cirsium arvense). Weed Technol 18:784-794 
Gurda AM, Renz M, Emrich R (2014) Canada Thistle Suppression and Forage Production in Mob Grazed Pastures. M.S. Thesis. Madison, WI: University of Wisconsin-Madison. $64 \mathrm{p}$

Hancock DW (2010) Nitrate toxicity. University of Georgia Extension C 915. Athens, Georgia

Harrington KC, Horne DJ, Kemp PD (2014) Can differences in Cirsium arvense and Rumex obtusifolius densities within pastures be explained by soil parameters? New Zealand Plant Protection 67:238-244

Henning JC, Wheaton HN (1993) White, Ladino and Sweet Clover. University of Missouri Extension G4639.

Henning JC, Wheaton HN, Roberts CA (1993) Tall Fescue. University of Missouri Extension G4646.

Kerr L, Johnson B, Burrows G (1986) Intoxication of cattle by Perilla frutescens (purple mint). Vet. Hum. Toxicol. 28:412-416

Kok LT, McAvoy TJ, Mays WT (1986) Impact of tall fescue grass and Carduus thistle weevils on the growth and development of musk thistle (Carduus nutans). Weed Sci: 34:966-971

Marten GC, Andersen RN (1975) Forage nutritive value and palatability of 12 common annual weeds. Crop Sci. 15:821-827

Marten GC, Sheaffer CC, Wyse DL (1987) Forage nutritive value and palatability of perennial weeds. Agron. J. 79:980-986

Marten GC (1978) The animal-plant complex in forage palatability phenomena. J. Anim. Sci. 46:1470-1477

USDA UERSa (2015) Missouri Agricultural Overview, 2015 in USDA ERSa, ed,: National Agricultural Statistics Service

Panter K, Keeler R, Baker D (1988) Toxicoses in Livestock from the Hemlocks (and Spp.). J. Anim. Sci. 66:2407-2413

Peters E, Lowance S (1974) Fertility and management treatments to control broomsedge in pastures. Weed Sci. 22:201-205

Pfost DL, Gerrish JR, Davis M, Kennedy M (2000) Managed grazing systems and fencing for distribution of beef manure. University of Missouri Extension EQ379.

Roberts CA, Wheaton HN (1993) Renovating Grass Sods With Legumes. University of Missouri Extension G4651.

Rosenbaum KK, Bradley K, Roberts CA (2011) Influence of increasing common ragweed (Ambrosia artemisiifolia) or common cocklebur (Xanthium strumarium) densities on 
forage nutritive value and yield in tall fescue pastures and hay fields. Weed Technol 25:222-229

Sather BC, Kallenbach RL, Sexten WJ, Bradley KW (2013) Evaluation of Cattle Grazing Distribution in Response to Weed and Legume Removal in Mixed Tall Fescue (Schedonorus phoenix) and Legume Pastures. Weed Technol 27:101-107

Smith R, Amaral-Phillips D, Lehmkuhler J (2017a) Grazing Systems. http://www2.ca.uky.edu/grazer/April 2013 Grazing Systems.php. Accessed February 20,2017

Smith R, Amaral-Phillips D, Lehmkuhler J (2017b) Rotational Grazing vs. Continous Grazing. http://www2.ca.uky.edu/grazer/May14 Rotational vs Continuous Grazing.php. Accessed February 20,2017

Steckel L, Rhodes N (2007) Perilla mint. University of Tennessee Agricultural Extension W135.

Thompson A, Saunders AE, Martin P (1987) The effect of nodding thistle (Carduus nutans) on pasture production. Pages 22-25 in Proceedings of the 40th New Zealand Weed and Pest Control Conference. Palmerston North, New Zealand

Undersander D (2007) New developments in forage testing. Pages 26-34 in Proceedings of the Idaho

Alfalfa and Forage Conference. Twin Falls, ID

USDA NRCS (2016) Introduced, Invasive, and Noxious Plants, 2016 in Natural Resources Conservation Service 


\title{
Chapter II
}

\section{Relationships between Weed Incidence, Soil Fertility and pH, and Forage Parameters in Missouri Pastures}

\author{
Zachary L. Trower and Kevin W. Bradley
}

Across the 2015-2016 growing seasons, 43 mixed tall fescue and legume pastures were surveyed to determine the effects of selected soil and forage parameters on the density of individual weed species and overall weed density. The parameters included soil phosphorus $(\mathrm{P})$, potassium $(\mathrm{K})$, magnesium $(\mathrm{Mg})$ and calcium $(\mathrm{Ca})$ concentration, soil $\mathrm{pH}$, cation exchange capacity (CEC), cattle grazing density, total forage groundcover density, tall fescue density, and beneficial legume density, which was comprised of white clover, red clover and annual lespedeza densities. Sampling areas were established in each pasture at a frequency of one representative $20 \mathrm{~m}^{2}$ area per 4 ha of pasture. Once established, survey locations were sampled every 14 days during a period from April through September. Weed density was divided into categories (total, annual broadleaves, perennial broadleaves, and annual grasses) and also by the most common individual weed species encountered. These datasets were then divided into 3 timings, spring (April-May), summer (June-July), and fall (August-September), and then analyzed using regression tree models. Across all weed types and species, forage groundcover density was the main parameter that affected weed density. Soil K, P, and Mg levels also impacted weed density for many life cycles and weed species. Soil K level was the primary parameter that reduced density of common ragweed in the summer and fall timeframes, and this is 
one of the most common weed species encountered in Missouri pastures. Similarly, soil P level was the primary parameter that reduced perennial broadleaf weed density in the summer and fall timeframes; when $\mathrm{P}$ was greater than $1.5 \mathrm{ppm}$, there was a 66 and 59\% reduction in the density of these species in the summer and fall timeframes, respectively. Cattle grazing densities less than 1.2 units per acre also resulted in fewer annual grass weeds in pastures. Results from this survey indicate that maximizing the groundcover of beneficial forage species is the most important factor that results in weed density reductions in mixed tall fescue and legume pastures, followed by proper maintenance of soil nutrients like $\mathrm{P}$ and $\mathrm{K}$.

\section{Introduction}

Grassland pastures and rangeland make up an estimated 214 million ha, or approximately $29 \%$ of the total land area of the United States and approximately 2.8 million ha of land in Missouri (USDA ERS 2012). Pastures serve as the predominant source of nutrition for most of the beef cattle in Missouri, and throughout much of the Lower-Midwest. Tall fescue (Lolium arundinacea Shreb.) is the predominant forage grass found in pastures throughout the Midwest, but most pastures are a mix of tall fescue and other legume and grass species, which allows for a higher quality forage compared to a single species system (Glenn et al. 1981; Gerrish and Roberts 1999). Mixed tall fescue and legume pastures have the potential to be productive, but improper management of these systems can limit productivity and allow weeds to invade. 
Annual, biennial, and perennial weed species are the number one pest found in tall fescue pastures in the United States. It has been estimated that weed infestations cause 2 billion dollars in loss annually in the United States (Bovey 1987). Weeds in a pasture setting can take nutrients away from the desired forage, often decreasing forage yields and nutritive value, and often result in areas in the pasture that will not be grazed (Bovey 1987; Grekul and Bork 2004; Gylling and Arnold 1983; Watson 1976). Not only do weeds compete for water and nutrients, they also form a canopy interfering with light interception (Toler et al. 1996). When pastures have improper soil $\mathrm{pH}$ and/or low nutrient levels, weed competition is greater, as these conditions favor the emergence, propagation, and growth of weeds while hindering the growth of the desirable forage (DiTomaso 2000; Green and Martin 1998).

Though not extensively studied, the presence of certain pasture weeds has been correlated with specific soil nutrition and $\mathrm{pH}$ levels. For example, broomsedge (Andropogon virginicus L.), a common pasture weed in Missouri, was eliminated through increased competition of the forage within a 4 year time period because of the addition of nitrogen $(\mathrm{N})$, potassium $(\mathrm{K})$, and phosphorus (P) fertilizer (Peters and Lowance 1974). Musk thistle seed production was also reduced by 89 to $97 \%$ when in competition with a well-established stand of tall fescue (Kok et al. 1986). These examples illustrate that maintaining optimum soil $\mathrm{pH}$ and nutrient levels allows the perennial forage to outcompete many weed species. Conversely, some weeds respond positively to increases in specific soil nutrients or $\mathrm{pH}$. In one study conducted with broadleaf dock (Rumex obtusifolius) and Canada thistle, both species correlated positively to increasing K levels 
with significant Pearson correlation coefficient values of 0.37 and 0.3 (Harrington et al. 2014).

The choice of grazing system can also have an influence on weed incidence in a pasture setting. There are 3 major grazing systems implemented in Missouri; continuous, rotational, and intensive grazing. Each system has it benefits and drawbacks, but one of the biggest disadvantages of any grazing system is uneven grazing that leads to increased weed incidence and growth (Blackburn 1984). As weed incidence increases within a pasture, cattle will avoid that area in favor of an area with fewer weeds. Sather et al. (2013) reported that cattle distribution was 1.3 to 5 times greater in areas where weeds were treated with a herbicide than areas where weeds were left uncontrolled (Sather et al. 2013). The challenge of overgrazing can be managed with rotational or intensive grazing, where cattle are moved regularly, but certain areas can still be overgrazed.

Currently, there is little research on the interaction between soil properties, forage and grazing parameters and their relationship between weed incidence and severity in pastures over a range of geographies and soil types. Therefore, the objective of this research was to determine the effects of soil nutrients, soil $\mathrm{pH}$, and other grazing and forage system components on weed incidence and severity in mixed tall fescue and legume pastures in Missouri.

\section{Materials and Methods}

Site Description. Field surveys were conducted during the 2015 and 2016 growing seasons at 43 locations across the state of Missouri (Figure 2.1, Table 2.1). Each pasture 
that was surveyed consisted of mixed tall fescue and legumes such as white clover, red clover, and annual lespedeza. Specific site information such as year surveyed, GPS location, soil type, and pasture size are presented in Table 2.1. Management restrictions were placed before and during the survey to ensure no herbicide or lime applications were made, and that cattle were actively grazing each pasture survey location throughout the season.

The experiment was conducted on an acreage based survey system. A single 20 $\mathrm{m}^{2}$ representative sampling location was established for each 4 ha of pasture at each site. Sampling locations were randomly established while trying to represent the pasture variance as accurately as possible. During establishment, the center of each sampling area was georeferenced with a Trimble GeoExplorer 2008 Series (Trimble Inc., 935 Stewart Drive, Sunnyvale, California 94085) to ensure the exact same sampling area would be revisited and surveyed every 14 days.

Data Collection. The average size of the 43 survey locations was 23.4 ha (range 14.1 to 48.6 ha). After sampling areas were established, each location was sampled on 14-day intervals for a total of 12 surveys with the survey dates beginning in early April and continuing through October $2^{\text {nd }}$. At the time of each survey, a variety of weed and forage data were collected. At the time of each survey all weed species within the $20 \mathrm{~m}^{2}$ sampling area were counted and the average height of each individual weed species was determined. Additionally, each weed species was visually assessed for clear indications of whether that species had been grazed or avoided by cattle. Some indications of grazing would include grazed portions of a plant, or actual observations of cattle grazing that species. Evidence of avoidance included grazing up to and around a given weed species, 
but no evidence of cattle grazing on the weed itself. All forage grass and legume species were also identified within the $20 \mathrm{~m}^{2}$ area, and a visual assessment of the total groundcover contribution of each forage species was made along with the average height of all forage species present. Visual assessment of groundcover was conducted by first determining how much of the survey area was covered in forage, and then estimating how much each forage component made up of the total forage groundcover percentage. On the $6^{\text {th }}$ survey timing (mid-July), soil samples were collected to a depth of 6 inches from each sampling area. The samples were taken at that timing to allow for any fertilizer applied in the beginning of the season to incorporate into the soil solution. Soil samples were analyzed for $\mathrm{P}, \mathrm{K}$, magnesium $(\mathrm{Mg})$, calcium $(\mathrm{Ca}), \mathrm{pH}$, and cation exchange capacity (CEC).

Data analysis. Weed density was considered the primary response variable in all analyses. Weed species were analyzed according to total weed density, annual broadleaf weeds, perennial broadleaf weeds, and annual grass weeds. The most common weed species encountered in the survey were also analyzed individually. Data were divided into 3 timeframes; spring (April-May), summer (June-July), and fall (August-September) to account for the different trends of weed density and emergence that typically occur in mixed tall fescue and legume pastures during the season. Selected weed species are featured in table 2.2, as well as the primary, secondary, and tertiary parameters that effect weed density for that time period and weed category.

The predictors measured and tested against weed density included soil $\mathrm{P}, \mathrm{K}, \mathrm{Mg}$ and $\mathrm{Ca}$ concentration, soil $\mathrm{pH}, \mathrm{CEC}$, cattle grazing units per acre, total forage groundcover density, tall fescue density, and beneficial legume density which was the 
combined total of white clover, red clover and annual lespedeza densities. Cattle grazing units per acre were determined using standards based off of Oklahoma State. Predictive models were developed using a regression tree analysis using the $\mathrm{R}$ statistical environment (R Core Team, 2013) with the packages "rpart" (Therneau et al. 2014) and "rpart.plot" (Milborrow 2014). Each decision tree begins with a root node containing the entire data set. This node is analyzed and split by the predictor that results in the greatest reduction in data variability within each of the descendant nodes (Breiman et al. 1984). This process of node splitting is continued until the parent nodes can no longer be split or the node contains $<1 \%$ of the total data set. These trees were then pruned using an automatically calculated complexity parameter associated with the smallest crossvalidated error (Breiman et al. 1984).

\section{RESULTS AND DISCUSSION}

Total weed density. Across all sites surveyed, the average weed density for the spring, summer and fall sampling periods was 69,78 , and 80 total weeds per $20 \mathrm{~m}^{2}$, respectively (Figures 2.2-2.4). Across 43 sites, the parameter that explained the largest amount of variance in total weed density was forage groundcover. Forage groundcover explained 15,20 , and $16 \%$ of the variance for the spring, summer, and fall timeframes, respectively (data not shown). When forage groundcover density was greater than 91,70 , and $76 \%$ in the spring, summer, and fall timeframes, respectively, weed density was reduced on average by 49,44 , and $52 \%$ (Figures $2.2-2.4$ ). Forage groundcover density was also the second most important variable for the summer and fall pooled datasets and reduced 
weed density by 50 to $61 \%$ for the respective regression trees (Figures $2.3 ; 2.4$ ). Models explained 33,46 , and $41 \%$ of the total variability of the datasets for the spring, summer, and fall timeframes, respectively (Figures 2.2-2.4). All other variables in the pruned regression trees for overall weed density individually explained less than $5 \%$ of the total variance observed (data not shown). However, some of the variables that impacted overall weed density included $\mathrm{P}, \mathrm{Mg}$ and $\mathrm{Ca} \mathrm{ppm}, \mathrm{CEC}$, soil $\mathrm{pH}$, cattle units per acre and tall fescue density (Figures 2.2-2.4). Unlike row crop systems, pastures have a greater potential to contain a wide variety of different broadleaf and grass species with annual, biennial, and perennial life cycles and variable times of emergence. This could explain why other variables did not play a greater role in this research.

Annual Broadleaf Weeds. As with total weed density, the parameter that explained the most variance for annual broadleaf density was forage groundcover density for the spring and summer timeframes (Figures 2.5-2.6), but this was not the case for the fall timeframe. When forage groundcover density was greater than 92 and $66 \%$ in the spring and summer timeframes, there were 57 and 56\% fewer annual broadleaf weeds, respectively (Figures 2.5 and 2.6). In the fall timeframe, however, $\mathrm{Mg}$ was the parameter that explained the most variance (Figure 2.7). When $\mathrm{Mg}$ was less than $462 \mathrm{ppm}$, there was a $67 \%$ reduction in annual broadleaf weeds per $20 \mathrm{~m}^{2}$ (Figure 2.7). For the fall timeframe, forage groundcover density was the second most important parameter. When forage groundcover density was greater than $54 \%$, average annual broadleaf density decreased by $53 \%$ (Figure 2.7 ). These models explained 48,61 , and $61 \%$ of the total variability for the spring, summer, and fall timeframes, respectively (Figures 2.5-2.7). 
Tall fescue, the main forage grass encountered in Missouri pastures, has a bimodal growth habit. The greatest periods of growth and highest yields of tall fescue usually occurs in April or May and then in August and September. Based on the results from these experiments, it is likely that the higher forage density and height shades and prevents the germination of many annual broadleaf species that do not have enough stored reserves to grow through the tall fescue canopy. This explains why forage groundcover is the most influential factor in the spring timeframe and the percent coverage of the total forage is so high (>92\%). During the summer timeframe, tall fescue growth slows and the canopy opens, which allows many annual broadleaves to begin to germinate. In August-September, Mg concentration became the most influential factor for annual broadleaf density rather than forage groundcover. Two other nutrients that were influential across all three timeframes were $\mathrm{Ca}$ and $\mathrm{K}$ concentrations.

Perennial Broadleaf Weeds. The average weed density for perennial broadleaf weeds for the spring, summer, and fall timeframes was 21,30 , and 29 plants per $20 \mathrm{~m}^{2}$, respectively (Figures 2.8-2.10). Perennial broadleaf weed density was best explained by the forage groundcover density in the spring timeframe (Figure 2.8) and P levels in the summer and fall timeframes (Figures 2.9-2.10). When $\mathrm{P}$ was greater than $1.5 \mathrm{ppm}$, there was a 66 and 59\% reduction in weed density in the summer and fall timeframes, respectively (Figures $2.9 ; 2.10$ ). Phosphorus is an important nutrient for root development and plant establishment in tall fescue systems (Henning et al. 1993). Reinbott and Blevins (1994) also showed that when soil temperatures where $<15^{\circ} \mathrm{C}$, the addition of 20 or 28 $\mathrm{kg} \mathrm{ha}^{-1} \mathrm{P}$ increased $\mathrm{Mg}$ and $\mathrm{Ca}$ concentrations in tall fescue leaves, which can reduce the risk of grass tetany in cattle (Reinbott and Blevins 1994). When tall fescue has a more 
extensive and developed root system, it has the potential to compete better with weeds for nutrients and water, potentially lowering weed density. A study by Peters and Lowance (1974) showed that with the addition of $112 \mathrm{~kg} \mathrm{ha}^{-1}$ of phosphate and $112 \mathrm{~kg} \mathrm{ha}^{-1}$ potash eliminated broomsedge populations after 4 years (Peters and Lowance 1974). Forage groundcover density was the third most important parameter resulting in a 50, 47, and $76 \%$ reduction in perennial broadleaf weed density for the spring, summer, and fall timeframes, respectively (Figures $2.8-2.10$ ).

Annual Grass Weeds. Annual grass density per $20 \mathrm{~m}^{2}$ was 25 and 30 weeds for the summer and fall timeframes, respectively (Figures $2.11 ; 2.12$ ). Forage groundcover density greater than $64 \%$ was the secondary factor influencing weed density for the fall timeframe, resulting in a decrease of $57 \%$ weeds per $20 \mathrm{~m}^{2}$ (Figures 2.12). In the summer timeframe, a CEC level greater than 6.8 resulted in an $84 \%$ reduction in annual grass density per $20 \mathrm{~m}^{2}$. Cattle grazing units per acre reduced annual grass density during the summer timeframe when they were less than 1.2 units per acre resulting in $69 \%$ fewer weeds per $20 \mathrm{~m}^{2}$ (Figures 2.11). Regression tree models explained 54 and $61 \%$ of the variability of the summer and fall datasets, respectively (Figure $2.11 ; 2.12$ ). Yellow foxtail is the most common annual grass species that occurred in our survey pastures late in the season. Thus when cattle are put on pastures at higher densities in the summer, we observed that more annual grass species invaded in the fall timeframe, potentially due to a reduced canopy cover from grazing. In the fall timeframe, cattle densities between 0.05 and 1.2 units per ha reduced annual grass density by $53 \%$. This may be explained by the fact that when there is less forage available, cattle chose to graze annual grass weeds. 
Marten and Andersen (1975) also showed that yellow foxtail is as palatable as oats to sheep (Marten and Andersen 1975).

Individual weed species relationships. During the spring, summer and fall timeframes, across all 13 weed species, the most frequent primary, secondary, and third parameter that was observed was forage groundcover density, K level and forage groundcover density, respectively (Table 2.2). Harrington et al. (2014) also showed that broadleaf dock density was positively correlated to soil K levels and was negatively correlated with $\mathrm{Mg}$.

Common ragweed (Ambrosia artemisiifolia L.) is one of the most common weeds in Missouri pastures and also occurs in relatively high densities. In the summer and fall, soil K levels greater than 40 and 42 ppm resulted in 86 and $82 \%$ fewer common ragweed plants per $20 \mathrm{~m}^{2}$, respectively. Lanceleaf ragweed (Ambrosia bidentata Michx.) density was influenced most by forage groundcover densities while annual fleabane was most influenced by soil P levels. Soil P levels greater than $2.5 \mathrm{ppm}$ in the spring and summer timeframes resulted in 72 and $69 \%$ fewer annual fleabane, respectively. Soil P levels have been shown to be an influential factor in broomsedge density. Tall goldenrod and white snakeroot density were also highly influenced by soil P levels in the spring and fall timeframes. Peter and Lowance (1974) reported that the addition of $112 \mathrm{~kg} \mathrm{ha}^{-1}$ of phosphate and $112 \mathrm{~kg} \mathrm{ha}^{-1}$ potash eliminated broomsedge within 4 years due to increased forage competition.

Soil nutrient availability is dependent on soil $\mathrm{pH}$. If soil $\mathrm{pH}$ is acidic, many important macronutrients become less available to the desirable forage, limiting growth and health, which in turn allows for weeds to invade pasture environments (Green and 
Martin 1998). The average soil pH across all 43 locations was 5.8 (Figure 2.13), which would limit the availability of many important macronutrients such as $\mathrm{P}$ and $\mathrm{K}$. Besides a low average soil $\mathrm{pH}$, the median soil $\mathrm{P}$ level across 43 locations was $6 \mathrm{ppm}$, which shows that a large majority of pastures surveyed had P levels that were deficient and at levels than can limit overall pasture yield and growth (Figure 2.13). Since most of the sampling locations in the pastures surveyed were considered deficient in $\mathrm{P}$, this helps explain why when $\mathrm{P}$ was the primary parameter observed, the value for $\mathrm{P}$ ppm was so low (1.5-3.5 ppm). Soil K levels were more normally distributed than $\mathrm{P}$, so this nutrient tended to have a greater and more frequent effect on weed density. 


\section{Literature Cited}

Blackburn WH (1984) Impacts of grazing intensity and specialized grazing systems on watershed characteristics and responses. Developing Stratagies for Rangeland Management. Nat Res Council; Nat Acad Sci, Westview Press, Boulder, Colorado.

Bovey RW (1987) Weed control problems, Approaches, and Opportunities in Rangeland. Weed Sci 3;57-91

Breiman L, Friedman JH, Olshen RA, Stone CJ (1984) Classification and regression trees. Wadsworth, Belmont

DiTomaso JM (2000) Invasive Weeds in Rangelands: Species, Impacts and Management. Weed Sci 48: 255-265.

Glenn S, Glenn BP, Rieck CE, Ely DG, Bush LP (1981) Chemical quality, in vitro cellulose digestion, and yield of tall fescue forage affected by mefluidide. J Agric Food Chem 29:1158-1161

Green JD, Witt WW, Martin JR (2006) Weed Management in Grass Pastures, Hayfields, and Other Farmstead Sites. University of Kentucky Extension Service AGR-172.

Grekul CW, Bork EW (2004) Herbage yield losses in perennial pasture due to Canada thistle (Cirsium arvense). Weed Technol 18:784-794

Gylling SR, Arnold WE (1983) Effect of leafy spurge control on pasture productivity. Proc NCWSS. 38:100-103

Harrington KC, Horne DJ, Kemp PD (2014) Can differences in Cirsium arvense and Rumex obtusifolius densities within pastures be explained by soil parameters? New Zealand Plant Protection 67:238-244

Henning JC, Wheaton HN, Roberts CA (1993) Tall Fescue. University of Missouri Extension G4646.

Kok LT, McAvoy TJ, Mays WT (1986) Impact of tall fescue grass and Carduus thistle weevils on the growth and development of musk thistle (Carduus nutans). Weed Sci 34:966-971

Marten GC, Andersen RN (1975) Forage nutritive value and palatability of 12 common annual weeds. Crop Sci 15:821-827

Milborrow S (2014) rpart.plot: Plot rpart models. An enhanced version of plot.rpart. R package version 1.4-4. http://CRAN.R-project.org/ package=rpart.plot. Accessed Feburary 1, 2017 
Peters EJ, Lowance SA (1974) Fertility and management treatments to control broomsedge in pastures. Weed Sci 22:201-205

Reinbott TM, Blevins DG (1994) Phosphorus and Temperature Effects on Magnesium, Calcium, and Potassium in Wheat and Tall Fescue Leaves. Agron J 86:523-529.

Sather BC, Kallenbach RL, Sexten WJ, Bradley KW (2013) Evaluation of Cattle Grazing Distribution in Response to Weed and Legume Removal in Mixed Tall Fescue (Schedonorus phoenix) and Legume Pastures. Weed Technol 27:101-107

Terneau TM, Atkinson BJ, Ripley BM (2014) rpart: Recursive partitioning and regression trees. R package version 4.1-8. Te R Project for Statistical Computing. http://CRAN.R-project.org/package=rpart Accessed February 1, 2017

Watson VH (1976) Weed control and nutritional benefits of Banvel and Weedmaster in warm season grass pastures. Proceedings 29th Ann Mtg South Weed Sci Society. 142.

[USDA] US Deparment of Agriculture Economic Research Service (2012) United States State Fact Sheet 2012. Washington, DC: U.S. Department of Agriculture 
Table 2.1. Site characteristics for each pasture location surveyed in 2015 and 2016. ${ }^{\mathrm{a}}$

\begin{tabular}{|c|c|c|c|c|c|c|c|}
\hline \multirow{2}{*}{$\begin{array}{l}\text { Survey } \\
\text { location }\end{array}$} & \multirow[b]{2}{*}{ Year } & \multirow[b]{2}{*}{ GPS coordinate } & \multicolumn{4}{|c|}{ Soil properties } & \multirow[b]{2}{*}{ Size } \\
\hline & & & Texture & OM & $\mathrm{pH}$ & CEC & \\
\hline & & & & $--\%--$ & & --meq-- & (Ha) \\
\hline Audrain1 & 2016 & $39.35274,-91.92041$ & Leonard silt loam & 3.0 & 5.8 & 16.0 & 32.4 \\
\hline Audrain2 & 2016 & $39.25948,-91.38110$ & Gorin silt loam & 2.1 & 5.7 & 9.1 & 16.2 \\
\hline Audrain3 & 2016 & $39.14795,-92.08267$ & Armstrong loam & 3.2 & 5.7 & 12.1 & 48.6 \\
\hline Audrain5 & 2016 & $39.38357,-91.42166$ & Crider silt loam & 2.2 & 6.1 & 10.6 & 24.3 \\
\hline Barton1 & 2015 & $37.54884,-94.45826$ & Barco loam & 5 & 5.4 & 14.1 & 14.2 \\
\hline Boone1 & 2016 & $38.90488,-92.26306$ & Armstrong loam & 3.9 & 6.8 & 14.0 & 20.2 \\
\hline Callaway1 & 2016 & $38.88450,-91.71568$ & Armster cobbly loam & 4.8 & 5.8 & 16.7 & 32.4 \\
\hline Chariton1 & 2015 & $39.47081,-92.94082$ & Grundy silt loam & 3.4 & 5.3 & 15.4 & 32.4 \\
\hline Chariton2 & 2015 & $39.63022,-92.99381$ & Armstrong loam & 3 & 5.9 & 14.9 & 28.3 \\
\hline Cooper1 & 2015 & $38.89027,-92.52972$ & Menfro silt loam & 3 & 5.3 & 13 & 40.5 \\
\hline Cooper2 & 2015 & $38.85299,-92.47108$ & Hartville silt loam & 3.6 & 6.5 & 16 & 20.2 \\
\hline Cooper3 & 2015 & $38.81666,-92.57087$ & Leslie silt loam & 3.5 & 5.2 & 12.5 & 12.1 \\
\hline Crawford 1 & 2016 & $37.91409,-91.12894$ & Hildebrecht silt loam & 2.2 & 6.4 & 9.0 & 16.2 \\
\hline Crawford2 & 2016 & $38.18060,-91.23511$ & Gravois silt loam & 1.7 & 6.6 & 7.3 & 16.2 \\
\hline Dade1 & 2015 & $37.47158,-93.85844$ & Goss silt loam & 6.8 & 6.2 & 15.2 & 24.3 \\
\hline Dade2 & 2015 & $37.34872,-93.90533$ & Pomme silt loam & 4.6 & 5.1 & 14.5 & 16.2 \\
\hline Dallas1 & 2015 & $37.72889,-93.13942$ & Viraton silt loam & 4.6 & 6.1 & 14.2 & 16.2 \\
\hline Dent 1 & 2016 & $37.58329,-91.71790$ & Lebanon and Hobson silt loams & 2.0 & 6.0 & 5.9 & 24.3 \\
\hline
\end{tabular}




$\begin{array}{lcllcccc}\text { Howard1 } & 2015 & 39.28156,-92.69848 & \text { Grundy silt loam } & 3.3 & 5.4 & 14.2 & 32.4 \\ \text { Howard2 } & 2015 & 39.03919,-92.81324 & \text { Menfro silt loam } & 4.1 & 5.4 & 20.3 & 20.2 \\ \text { Howell1 } & 2016 & 36.88707,-91.80091 & \text { Taherhill silt loam } & 3.5 & 5.8 & 6.9 & 20.2 \\ \text { Howell1 } & 2015 & 37.40146,-92.32824 & \text { Viraton silt loam } & 2.2 & 5.6 & 6.9 & 14.2 \\ \text { Howell2 } & 2015 & 37.38098,-92.35349 & \text { Viraton silt loam } & 3.3 & 5.3 & 8 & 28.3 \\ \text { Howell3 } & 2015 & 37.39518,-92.33871 & \text { Viraton silt loam } & 3.2 & 6.6 & 8.7 & 16.2 \\ \text { Jasper1 } & 2015 & 37.31187,-94.42010 & \text { Barco loam } & 5.3 & 6 & 13.5 & 14.2 \\ \text { Linn1 } & 2015 & 39.78806,-93.26204 & \text { Armstrong clay loam } & 2.8 & 5.2 & 15.1 & 20.2 \\ \text { Linn2 } & 2015 & 39.78135,-93.30681 & \text { Grundy silt loam } & 4 & 5.9 & 16.2 & 24.3 \\ \text { Linn3 } & 2015 & 39.88377,-93.31869 & \text { Armstrong clay loam } & 2.3 & 5.7 & 12.8 & 20.2 \\ \text { Linn4 } & 2015 & 39.93508,-93.24896 & \text { Armstrong clay loam } & 2.7 & 5.2 & 18.8 & 32.4 \\ \text { Macon1 } & 2015 & 39.76684,-92.46246 & \text { Keswick clay loam } & 3.6 & 6.6 & 16.9 & 14.2 \\ \text { Moniteau1 } & 2015 & 38.77083,-92.53566 & \text { Bluelick silt loam } & 3.8 & 6.1 & 13 & 40.5 \\ \text { Moniteau2 } & 2015 & 38.80460,-92.52985 & \text { Weller silt loam } & 3.1 & 4.8 & 15.3 & 16.2 \\ \text { Moniteau3 } & 2015 & 38.79086,-92.51227 & \text { Bluelick silt loam } & 3.6 & 5.4 & 11.2 & 16.2 \\ \text { Monroe1 } & 2016 & 39.54646,-92.17271 & \text { Mexico silt loam } & 3.7 & 5.6 & 16.5 & 24.3 \\ \text { Monroe2 } & 2016 & 39.54578,-91.80221 & \text { Leonard silt loam } & 3.1 & 5.2 & 12.1 & 32.4 \\ \text { Monroe3 } & 2016 & 39.53994,-91.76583 & \text { Armstrong loam } & 3.0 & 6.3 & 11.0 & 16.2 \\ \text { Randolph2 } & 2015 & 39.36348,-92.44735 & \text { Leonard silt loam } & 3.9 & 5.7 & 16 & 16.2 \\ \text { Rauls1 } & 2016 & 39.49586,-91.52676 & \text { Gorin silt loam } & 3.6 & 5.8 & 11.5 & 32.4 \\ \text { Rauls2 } & 2016 & 39.60349,-91.35433 & \text { Winfield silt loam } & 3.0 & 5.7 & 11.8 & 16.2\end{array}$




\begin{tabular}{|c|c|c|c|c|c|c|c|}
\hline Texas 1 & 2016 & $37.23875,-91.89613$ & Tonti silt loam & 2.7 & 6.0 & 5.0 & 16.2 \\
\hline Texas 2 & 2016 & $37.25777,-91.74920$ & Viburnum silt loam & 3.6 & 5.0 & 7.7 & 32.4 \\
\hline Texas3 & 2016 & $37.38831,-92.13380$ & Poynor very gravelly silt & 2.4 & 5.3 & 5.3 & 32.4 \\
\hline Texas4 & 2016 & $37.31559,-92.13347$ & Mano-Ocie complex & 2.3 & 6.2 & 4.4 & 20.2 \\
\hline
\end{tabular}

a Abbreviations: OM, organic matter; CEC, cation exchange capacity (meq/100 g soil). 
Table 2.2. First 3 parameters of respective regression trees and their effect on weed density. ${ }^{\text {a }}$

\begin{tabular}{|c|c|c|c|c|c|c|c|c|c|c|c|c|}
\hline \multirow[b]{2}{*}{ Selected Tree } & \multirow[b]{2}{*}{ Timeframe } & \multirow[b]{2}{*}{$\mathrm{n}$} & \multirow[b]{2}{*}{$\begin{array}{c}\text { Primary } \\
\text { parameter }\end{array}$} & \multicolumn{2}{|c|}{$\begin{array}{c}\text { Parameter } \\
\text { effect on } \\
\text { weed density }\end{array}$} & \multirow[b]{2}{*}{$\begin{array}{c}\text { Second } \\
\text { parameter }\end{array}$} & \multicolumn{2}{|c|}{$\begin{array}{c}\text { Parameter } \\
\text { effect on } \\
\text { weed density }\end{array}$} & \multirow[b]{2}{*}{$\begin{array}{c}\text { Third } \\
\text { parameter }\end{array}$} & \multicolumn{2}{|c|}{$\begin{array}{c}\text { Parameter } \\
\text { effect on } \\
\text { weed density }\end{array}$} & \multirow[b]{2}{*}{$\mathrm{R}^{2}$} \\
\hline & & & & True & False & & True & False & & True & False & \\
\hline Broadleaf P. ${ }^{b}$ & Spring & 118 & $\mathrm{pH}<6.8$ & 4.2 & 26 & & & & & & & .31 \\
\hline Broadleaf P. & Summer & 111 & $\mathrm{pH}<7$ & 2.5 & 11 & & & & & & & .54 \\
\hline Broadleaf P. & Fall & 92 & $\mathrm{pH}<7$ & 3 & 8.9 & Kppm $<91$ & 2 & 4 & Pppm > 3.5 & 1.4 & 2.6 & .50 \\
\hline Buckbrush & Spring & 238 & $\mathrm{CEC}>4.2$ & 10 & 43 & $\mathrm{Kppm}>72$ & 8.8 & 22 & G.C. $>76 \%$ & 6.8 & 15 & .44 \\
\hline Buckbrush & Summer & 249 & G.C. $>62 \%$ & 7.9 & 20 & $\mathrm{CEC}<16$ & 16 & 48 & G.C. $>82 \%$ & 5.2 & 11 & .58 \\
\hline Buckbrush & Fall & 205 & $\mathrm{CEC}<17$ & 8.6 & 31 & G.C. $>42 \%$ & 8.5 & 78 & Kppm > 72 & 7.5 & 18 & .64 \\
\hline Buckhorn P. & Spring & 203 & G.C. $>32 \%$ & 19 & 131 & G.C. $>91 \%$ & 9.3 & 27 & Pppm > 5.5 & 19 & 36 & .59 \\
\hline Buckhorn P. & Summer & 188 & Mgppm $<482$ & 14 & 146 & $\mathrm{Kppm}>85$ & 6.6 & 22 & G.C. $>74 \%$ & 15 & 37 & .69 \\
\hline Buckhorn P. & Fall & 149 & Mgppm < 506 & 13 & 120 & & & & & & & .41 \\
\hline C. Ragweed & Spring & 354 & Cappm > 750 & 27 & 80 & Units > .52 & 17 & 41 & B.L > 7.5\% & 31 & 98 & .59 \\
\hline C. Ragweed & Summer & 548 & $\mathrm{Kppm}>40$ & 22 & 159 & Units $>.52$ & 15 & 31 & Units $<.42$ & 21 & 56 & .57 \\
\hline C. Ragweed & Fall & 566 & $\mathrm{Kppm}>42$ & 20 & 109 & $\mathrm{CEC}<21$ & 18 & 51 & $\mathrm{pH}>6.2$ & 9.9 & 20 & .57 \\
\hline A. Fleabane & Spring & 331 & Pppm > 2.5 & 7.2 & 26 & $\mathrm{Kppm}>40$ & 6.8 & 17 & Cappm $<1915$ & 17 & 53 & .52 \\
\hline A. Fleabane & Summer & 293 & Pppm > 2.5 & 5.3 & 17 & Kppm > 64 & 4 & 9.1 & $\mathrm{Kppm}<80$ & 11 & 34 & .48 \\
\hline Horsenettle & Spring & 333 & G.C. $>50 \%$ & 5.4 & 23 & Units $<1.0$ & 4.5 & 8.9 & G.C. $>80 \%$ & 5.3 & 16 & .32 \\
\hline Horsenettle & Summer & 902 & Mgppm > 161 & 12 & 18 & Cappm > 728 & 11 & 26 & Mgppm < 148 & 15 & 33 & .48 \\
\hline Horsenettle & Fall & 931 & Cappm > 728 & 16 & 27 & Mgppm > 156 & 14 & 22 & Pppm $<31$ & 21 & 74 & .55 \\
\hline
\end{tabular}




\begin{tabular}{|c|c|c|c|c|c|c|c|c|c|c|c|c|}
\hline L. Ragweed & Summer & 274 & G.C. $>64 \%$ & 34 & 85 & Units > .24 & 69 & 155 & $\mathrm{CEC}<11$ & 24 & 85 & .51 \\
\hline L. Ragweed & Fall & 264 & G.C. $>54 \%$ & 27 & 65 & Mgppm < 445 & 57 & 114 & Units $>.36$ & 32 & 86 & .53 \\
\hline T. Goldenrod & Spring & 123 & Pppm > 1.5 & 9 & 35 & B.L. $<30 \%$ & 6.6 & 16 & Cappm > 1838 & 3.1 & 9.1 & .40 \\
\hline T. Goldenrod & Summer & 149 & G.C. $>20 \%$ & 8.2 & 49 & Pppm $<7$ & 6.2 & 16 & Cappm $<2981$ & 5.2 & 14 & .48 \\
\hline T. Goldenrod & Fall & 111 & Pppm > 1.5 & 7.6 & 40 & Pppm $<9$ & 5.5 & 22 & & & & .32 \\
\hline Ironweed spp. & Spring & 192 & Cappm $<2360$ & 5 & 11 & G.C. $>91 \%$ & 4.5 & 19 & $\mathrm{Kppm}>70$ & 3.8 & 7.9 & .43 \\
\hline Ironweed spp. & Summer & 321 & G.C. $>69 \%$ & 7.2 & 19 & $\mathrm{Kppm}>80$ & 10 & 33 & Cappm $<2770$ & 7 & 32 & .62 \\
\hline Ironweed spp. & Fall & 239 & Mgppm > 146 & 6.4 & 17 & Kppm > 70 & 11 & 40 & Units $<1.3$ & 5.4 & 12 & .48 \\
\hline Vervain spp. & Spring & 173 & B.L. > .05\% & 3.7 & 17 & $\mathrm{Kppm}<160$ & 8.4 & 38 & Cappm > 1053 & 3.7 & 18 & .50 \\
\hline Vervain spp. & Summer & 236 & G.C. $>54 \%$ & 4.5 & 18 & $\mathrm{Kppm}<162$ & 9.4 & 30 & Mgppm $<448$ & 4.3 & 12 & .46 \\
\hline Vervain spp. & Fall & 217 & Kppm $<178$ & 3.8 & 8 & G.C. $>64 \%$ & 2.9 & 5.7 & Mgppm < 202 & 4.5 & 9.6 & .57 \\
\hline W. Snakeroot & Spring & 75 & Pppm > 3.5 & 2.9 & 6 & $\mathrm{pH}>6.1$ & 2.9 & 8.5 & $\mathrm{pH}>5.5$ & 2 & 4.1 & .66 \\
\hline W. Snakeroot & Summer & 116 & $\mathrm{Kppm}<132$ & 4.5 & 8.8 & Cappm > 1012 & 5.8 & 16 & $\mathrm{Kppm}>178$ & 2.2 & 11 & .63 \\
\hline W. Snakeroot & Fall & 93 & Pppm > 3.5 & 4.6 & 15 & $\mathrm{Kppm}<60$ & 7 & 23 & Mgppm > 166 & 2.1 & 8.2 & .61 \\
\hline W. Croton & Spring & 43 & Mgppm > 216 & 4.4 & 9.1 & Mgppm > 406 & 3.1 & 5.8 & & & & .32 \\
\hline W. Croton & Summer & 224 & Mgppm > 340 & 4.1 & 16 & $\mathrm{CEC}<16$ & 14 & 42 & Kppm $<178$ & 12 & 33 & .45 \\
\hline W. Croton & Fall & 231 & Cappm > 775 & 8.5 & 16 & Cappm $<746$ & 9.4 & 58 & Mgppm > 122 & 7.2 & 22 & .39 \\
\hline Y. Foxtail & Summer & 65 & Kppm > 92 & 9.7 & 28 & T.F. $>22 \%$ & 7.6 & 21 & & & & .22 \\
\hline Y. Foxtail & Fall & 390 & $\mathrm{CEC}<23$ & 17 & 72 & $\mathrm{CEC}<12$ & 11 & 21 & G.C. $>64 \%$ & 13 & 31 & .52 \\
\hline
\end{tabular}

a Abbreviations: Kppm, potassium part per million; Pppm, phosphorus part per million; CEC, Cation exchange capacity; G.C., forage groundcover percentage; Mgppm, magnesium part per million; Cappm, calcium part per million; Units, cattle units per acre; B.L., Beneficial legume density; T.F., tall fescue density 
${ }^{\mathrm{b}}$ Abbreviations: Broadleaf P., Broadleaf plantain; Buckhorn P., Buckhorn plantain; C. Ragweed, Common ragweed; A. Fleabane, Annual fleabane; L. Ragweed, Lanceleaf Ragweed; T. Goldenrod, Tall Goldenrod; W. Snakeroot, White snakeroot; W. Croton, Woolly croton; Y. Foxtail, Yellow foxtail 


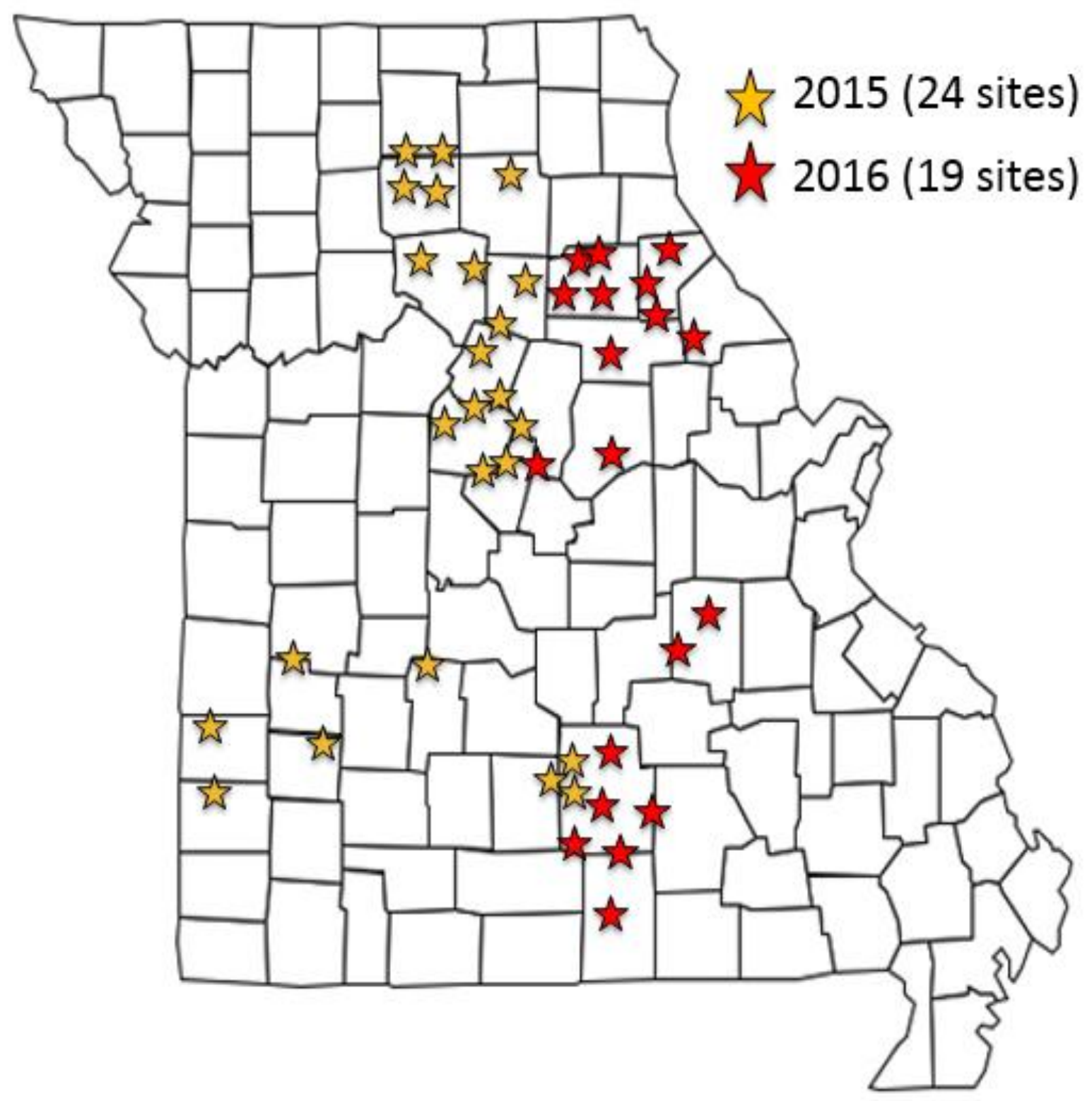

Figure 2.1. Location of pastures surveyed in Missouri. Gold stars represent the 24 locations surveyed in 2015, while red stars mark the 19 locations surveyed in 2016. 


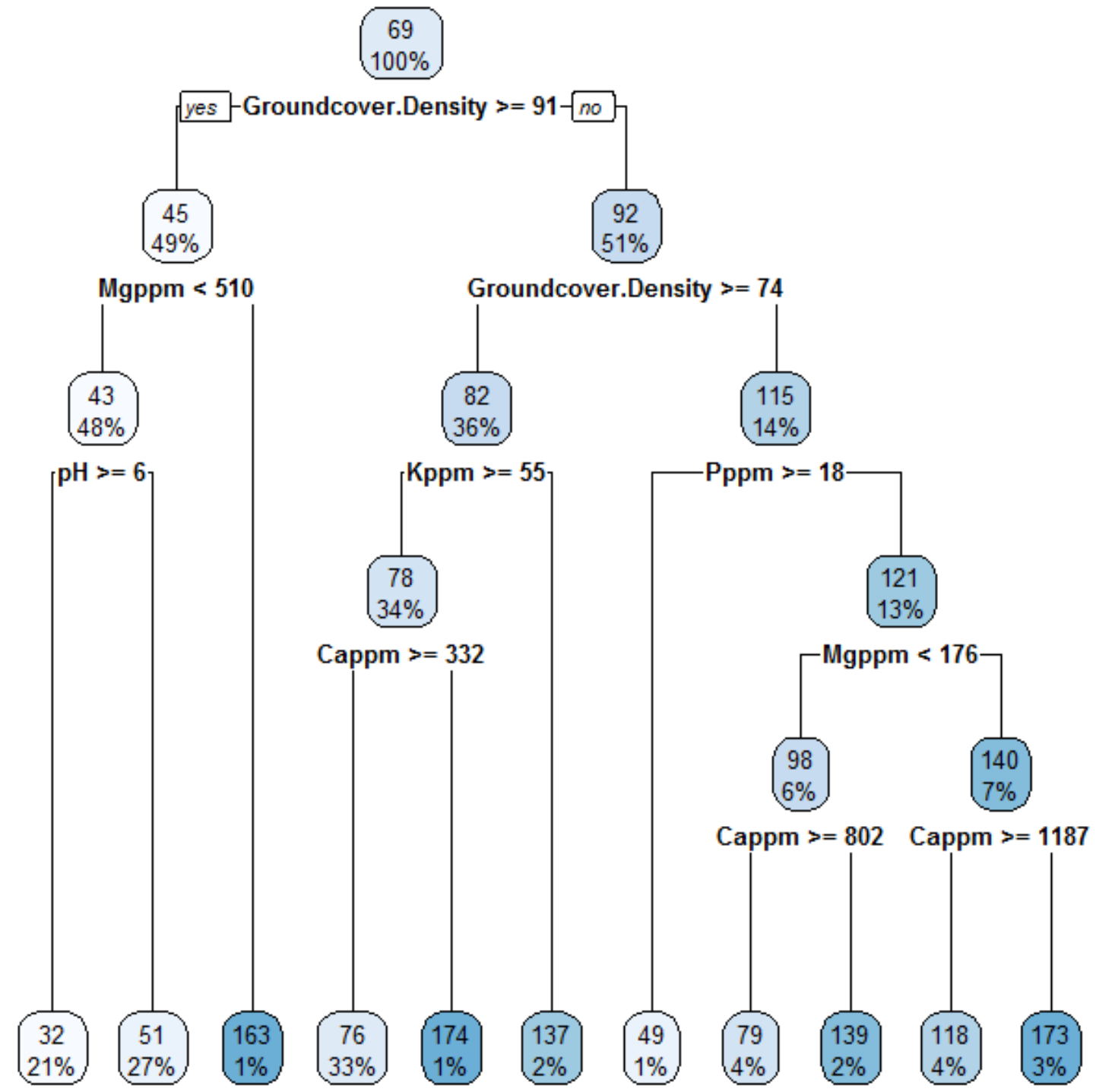

Figure 2.2. Regression tree predicting the average weed density per $20 \mathrm{~m}^{2}$ in the spring (April-May) timeframe $\left(\mathrm{R}^{2}=0.33\right)$. Abbreviations: Pppm, phosphorus part per million; Groundcover.Density, forage groundcover percentage; Mgppm, magnesium part per million; Cappm, calcium part per million. 


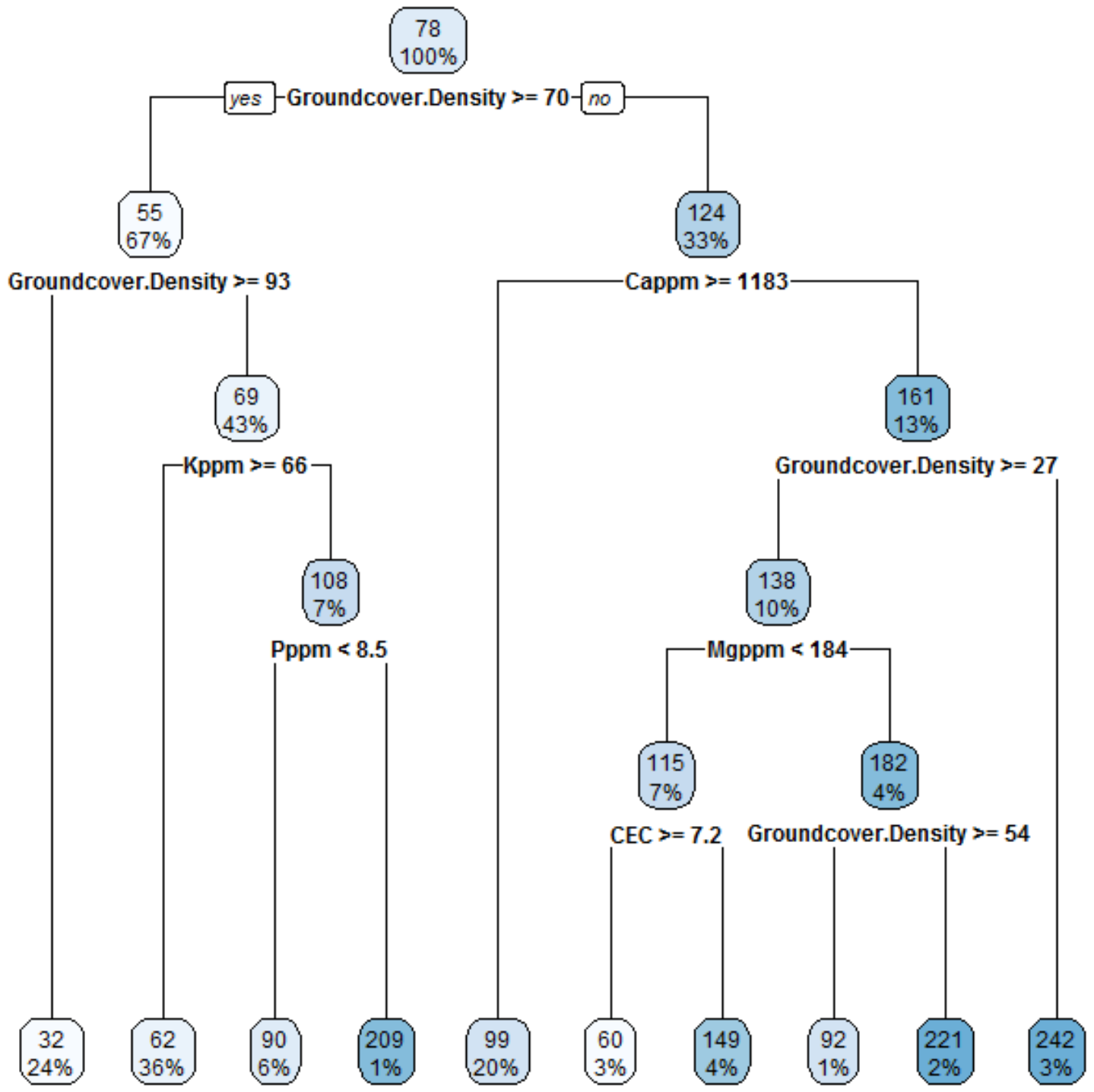

Figure 2.3. Regression tree predicting the average weed density per $20 \mathrm{~m}^{2}$ in the summer (June-July) timeframe $\left(\mathrm{R}^{2}=0.46\right)$. Abbreviations: Kppm, potassium part per million; Pppm, phosphorus part per million; Groundcover.Density, forage groundcover percentage; Mgppm, magnesium part per million; Cappm, calcium part per million; CEC, cation exchange capacity. 


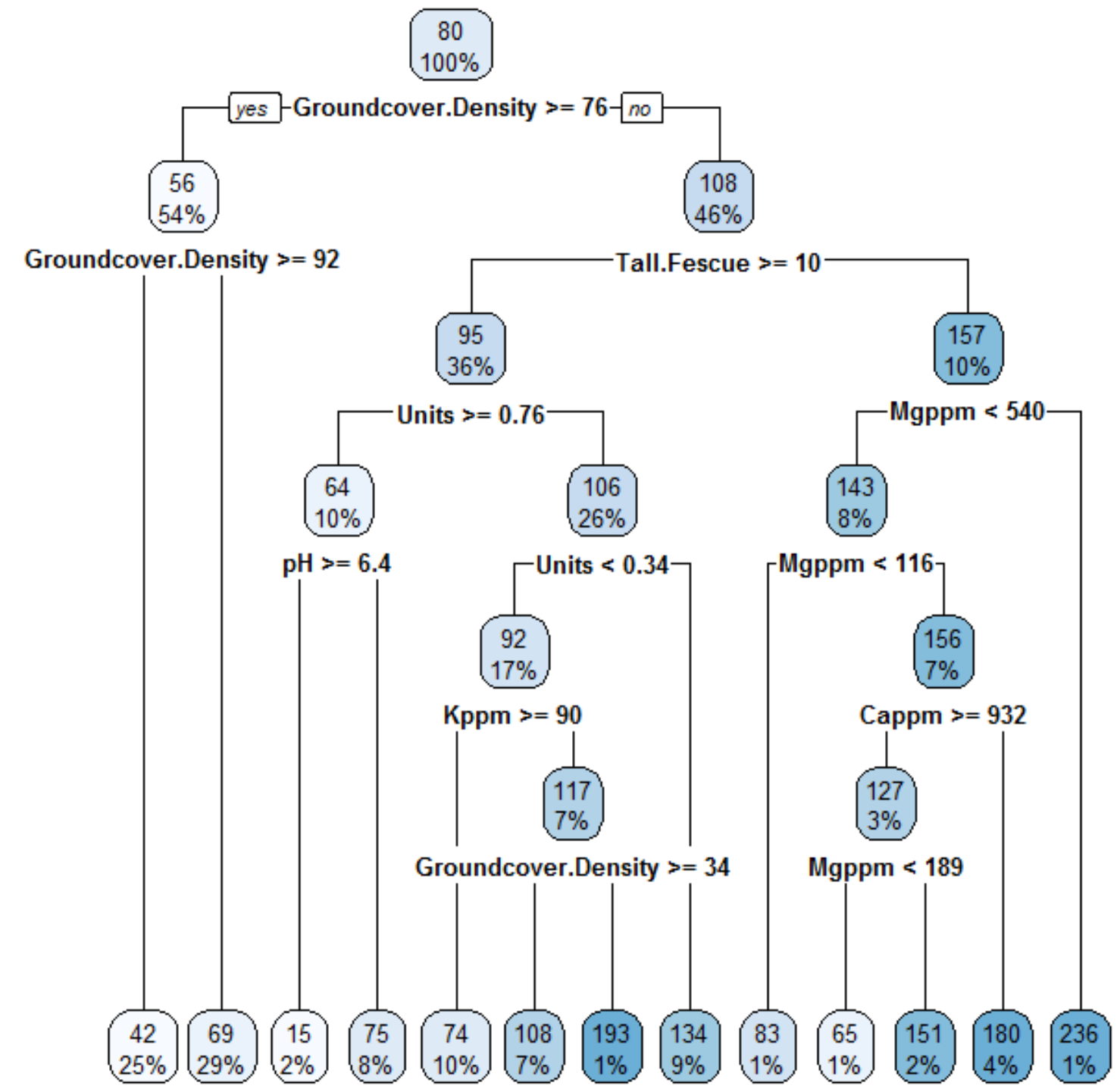

Figure 2.4. Regression tree predicting the average weed density per $20 \mathrm{~m}^{2}$ in the fall (August-September) timeframe $\left(\mathrm{R}^{2}=0.41\right)$. Abbreviations: Kppm, potassium part per million; Groundcover.Density, forage groundcover percentage; Mgppm, magnesium part per; million; Cappm, calcium part per million; Tall.Fescue, tall fescue density. 


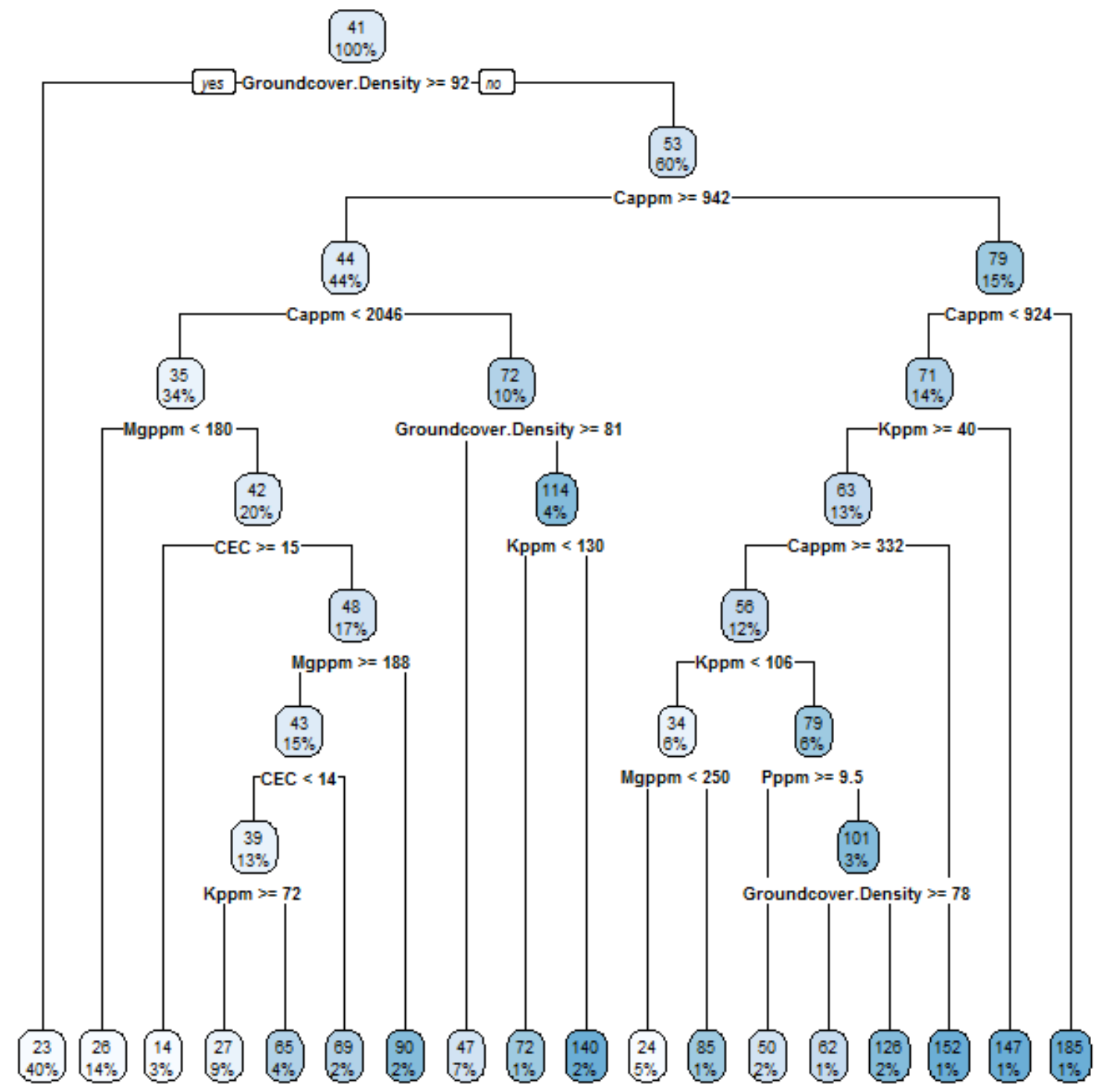

Figure 2.5. Regression tree predicting the average annual broadleaf density per $20 \mathrm{~m}^{2}$ in the spring (April-May) timeframe $\left(\mathrm{R}^{2}=0.48\right)$. Abbreviations: Kppm, potassium part per million; Pppm, phosphorus part per million; CEC, Cation exchange capacity; Groundcover.Density, forage groundcover percentage; Mgppm, magnesium part per; million; Cappm, calcium part per million. 


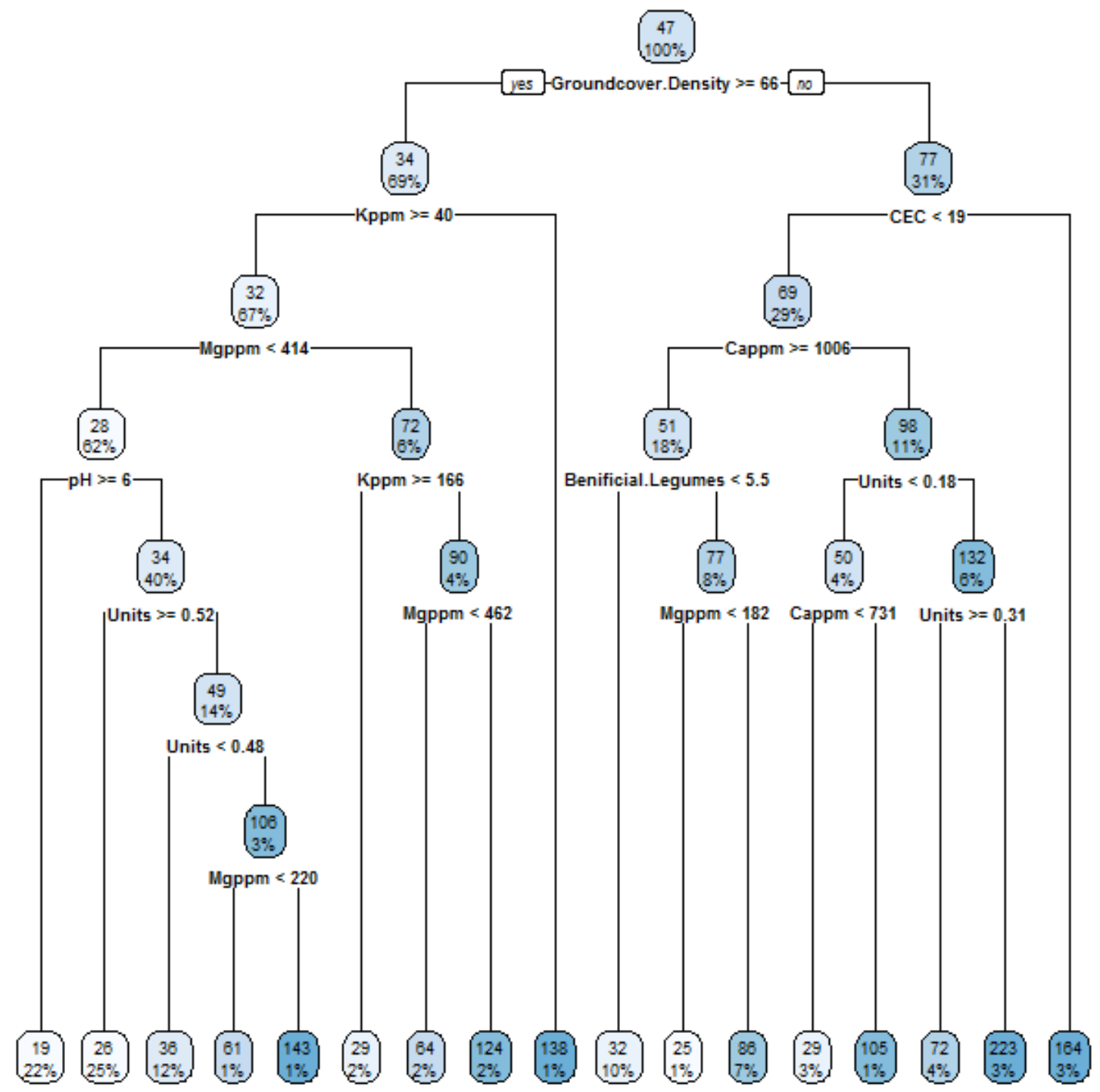

Figure 2.6. Regression tree predicting the average annual broadleaf density per $20 \mathrm{~m}^{2}$ in the summer (June-July) timeframe $\left(\mathrm{R}^{2}=0.61\right)$. Abbreviations: Kppm, potassium part per million; Pppm, phosphorus part per million; CEC, Cation exchange capacity; Groundcover.Density, forage groundcover percentage; Mgppm, magnesium part per; million; Cappm, calcium part per million; Units, cattle units per acre; Beneficial.Legume, Beneficial legume density. 


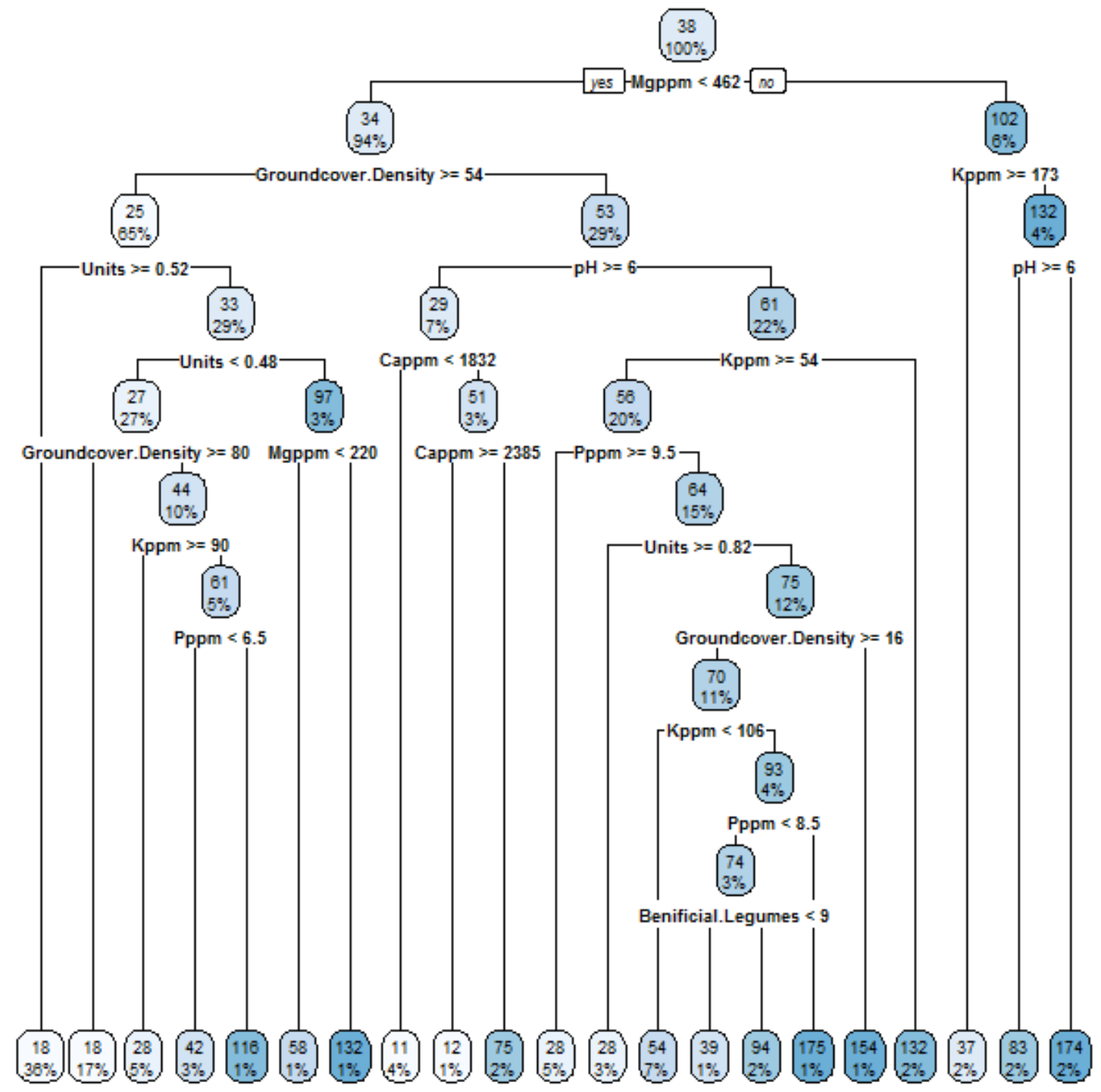

Figure 2.7. Regression tree predicting the average annual broadleaf density per $20 \mathrm{~m}^{2}$ in the fall (August-September) timeframe $\left(\mathrm{R}^{2}=0.61\right)$. Abbreviations: Kppm, potassium part per million; Pppm, phosphorus part per million; Groundcover.Density, forage groundcover percentage; Mgppm, magnesium part per; million; Cappm, calcium part per million; Beneficial.Legume, Beneficial legume density; Units, cattle units per acre. 


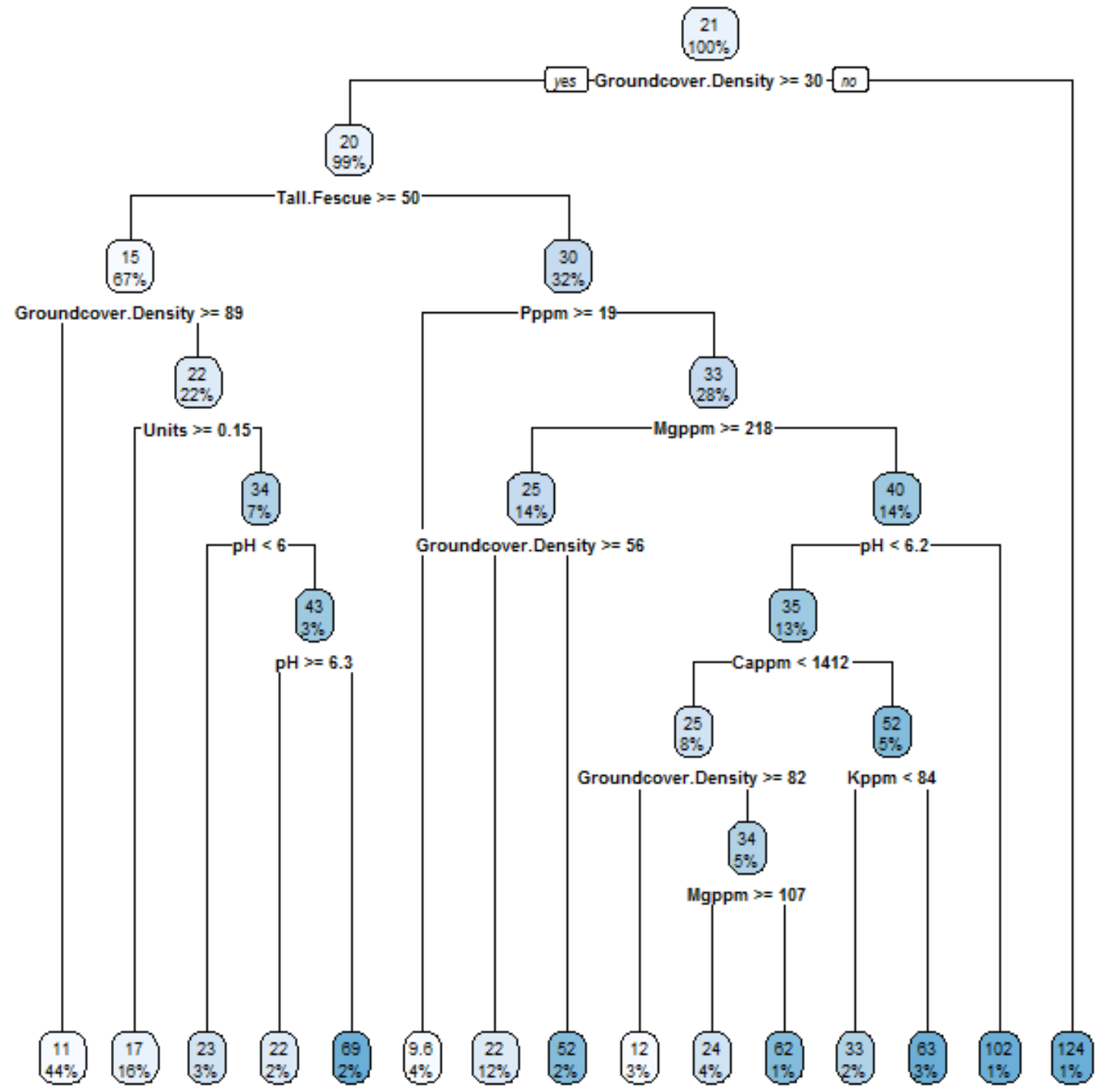

Figure 2.8. Regression tree predicting the average perennial broadleaf density per $20 \mathrm{~m}^{2}$ in the spring (April-May) timeframe $\left(\mathrm{R}^{2}=0.40\right)$. Abbreviations: Kppm, potassium part per million; Pppm, phosphorus part per million; Groundcover.Density, forage groundcover percentage; Mgppm, magnesium part per; million; Cappm, calcium part per million; Units, cattle units per acre. 


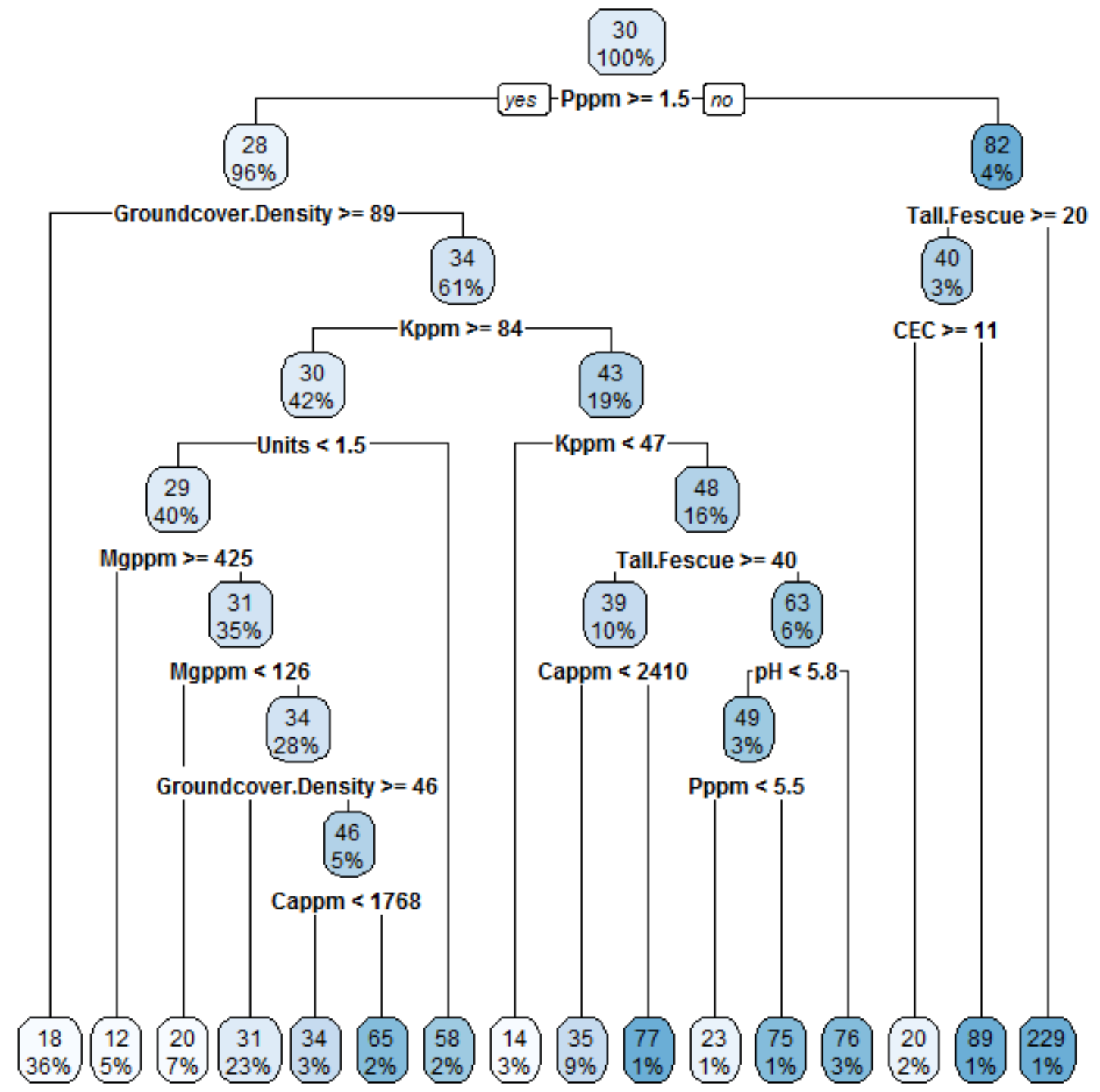

Figure 2.9. Regression tree predicting the average perennial broadleaf density per $20 \mathrm{~m}^{2}$ in the summer (June-July) timeframe $\left(\mathrm{R}^{2}=0.59\right)$. Abbreviations: Kppm, potassium part per million; Pppm, phosphorus part per million; CEC, Cation exchange capacity; Groundcover.Density, forage groundcover percentage; Mgppm, magnesium part per; million; Cappm, calcium part per million; Tall.Fescue, tall fescue density. 


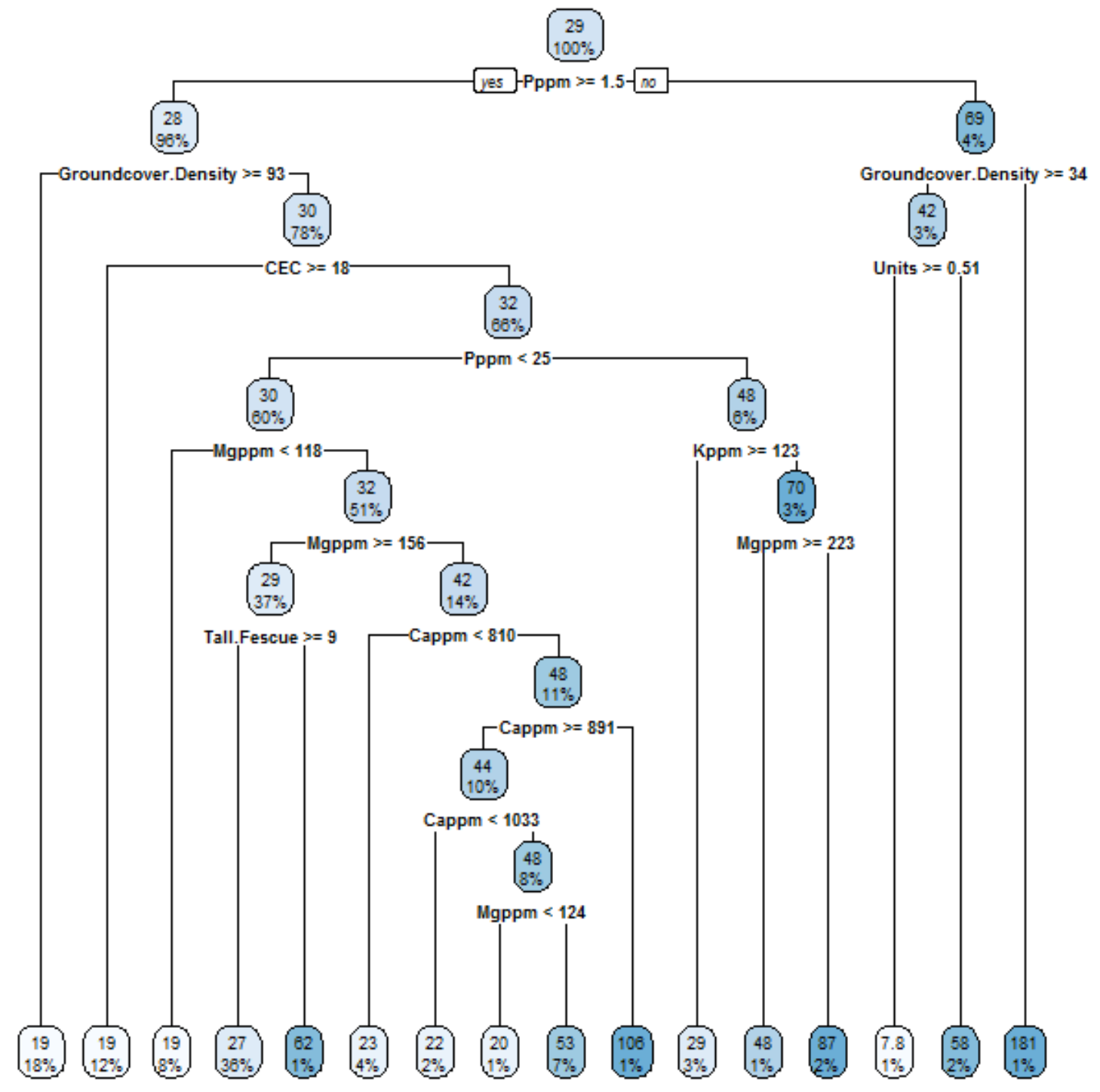

Figure 2.10. Regression tree predicting the average perennial broadleaf density per $20 \mathrm{~m}^{2}$ in the fall (August-September) timeframe $\left(\mathrm{R}^{2}=0.53\right)$. Abbreviations: Kppm, potassium part per million; Pppm, phosphorus part per million; CEC, Cation exchange capacity; Groundcover.Density, forage groundcover percentage; Mgppm, magnesium part per; million; Cappm, calcium part per million; Units, cattle units per acre. 


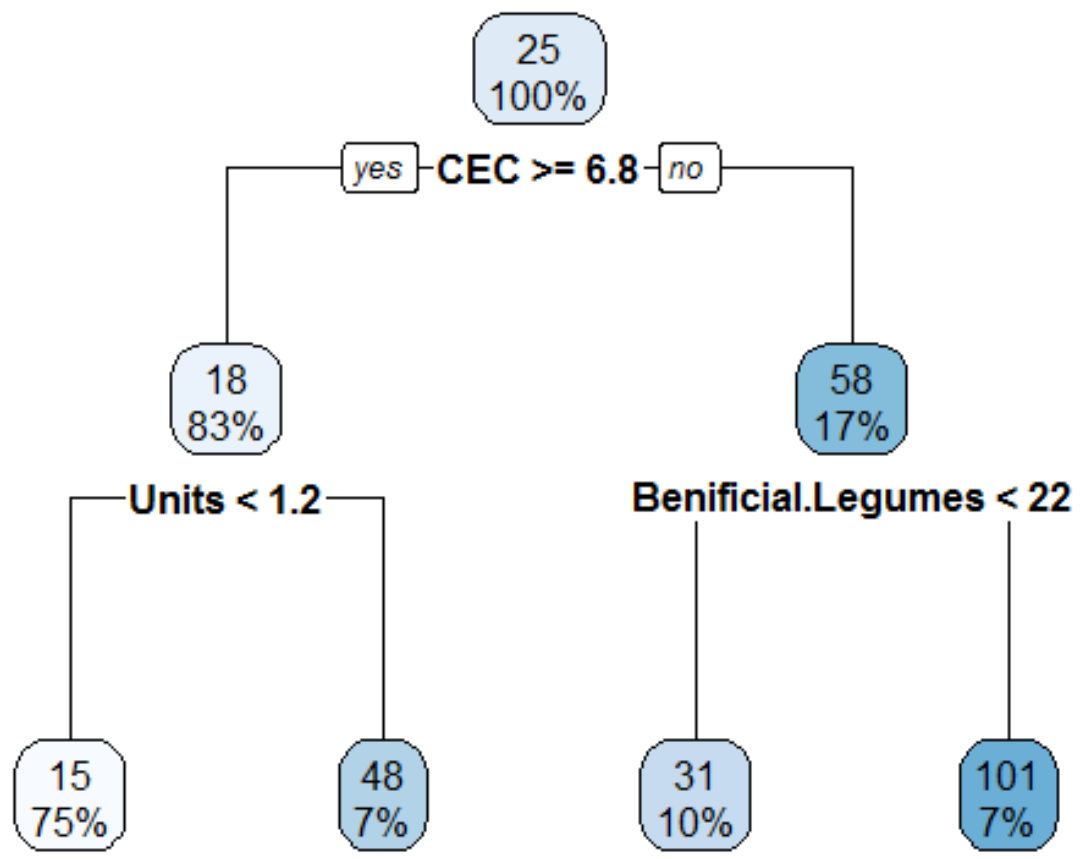

Figure 2.11. Regression tree predicting the average annual grass density per $20 \mathrm{~m}^{2}$ in the summer (June-July) timeframe $\left(\mathrm{R}^{2}=0.54\right)$. Abbreviations: CEC, Cation exchange capacity; Units, cattle units per acre; Beneficial.Legume, Beneficial legume density. 


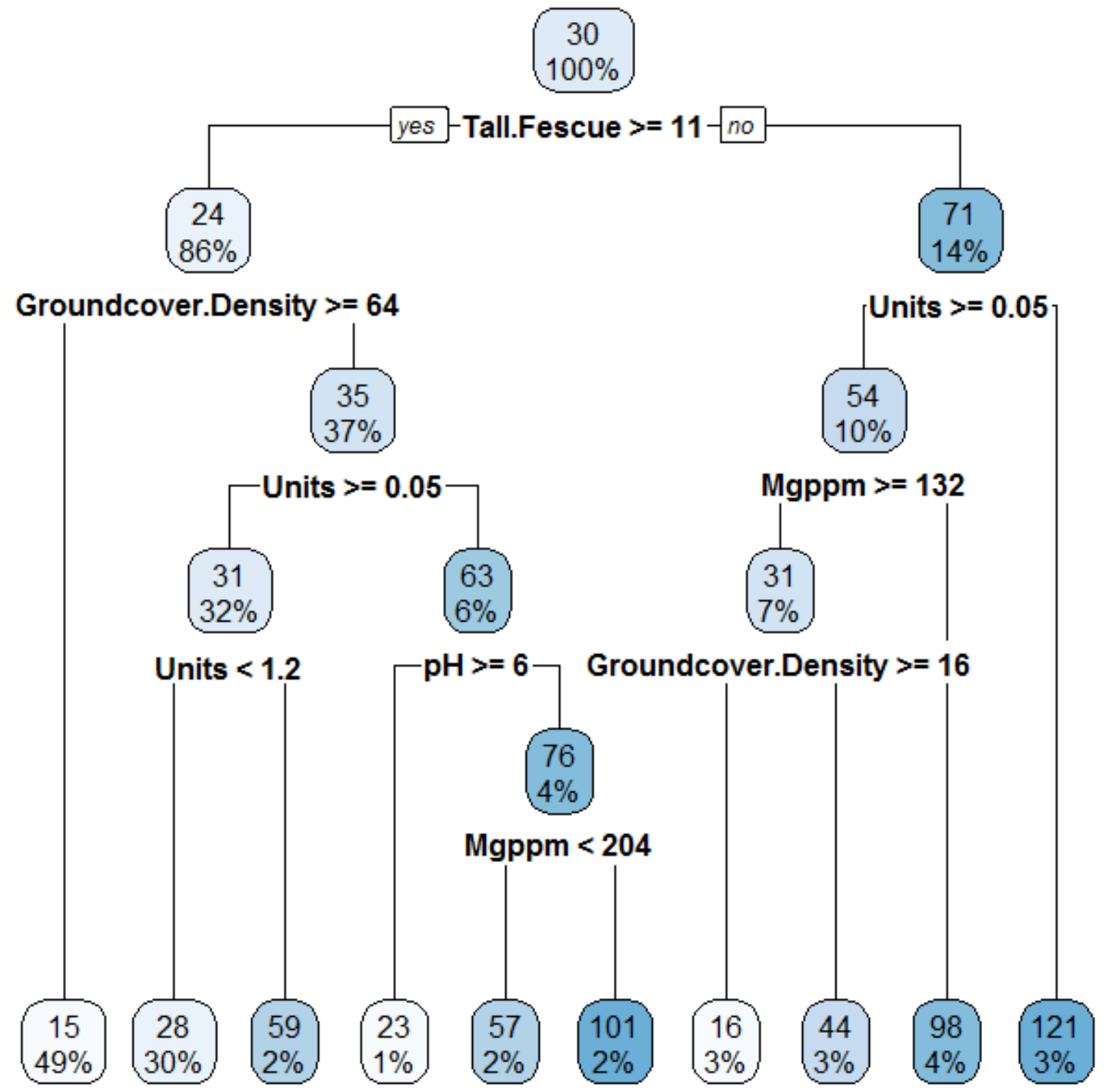

Figure 2.12. Regression tree predicting the average annual grass density per $20 \mathrm{~m}^{2}$ in the fall (August-September) timeframe $\left(\mathrm{R}^{2}=0.61\right)$. Abbreviations: Groundcover.Density, forage groundcover percentage; Mgppm, magnesium part per; million; Units, cattle units per acre; Tall.Fescue, tall fescue density. 


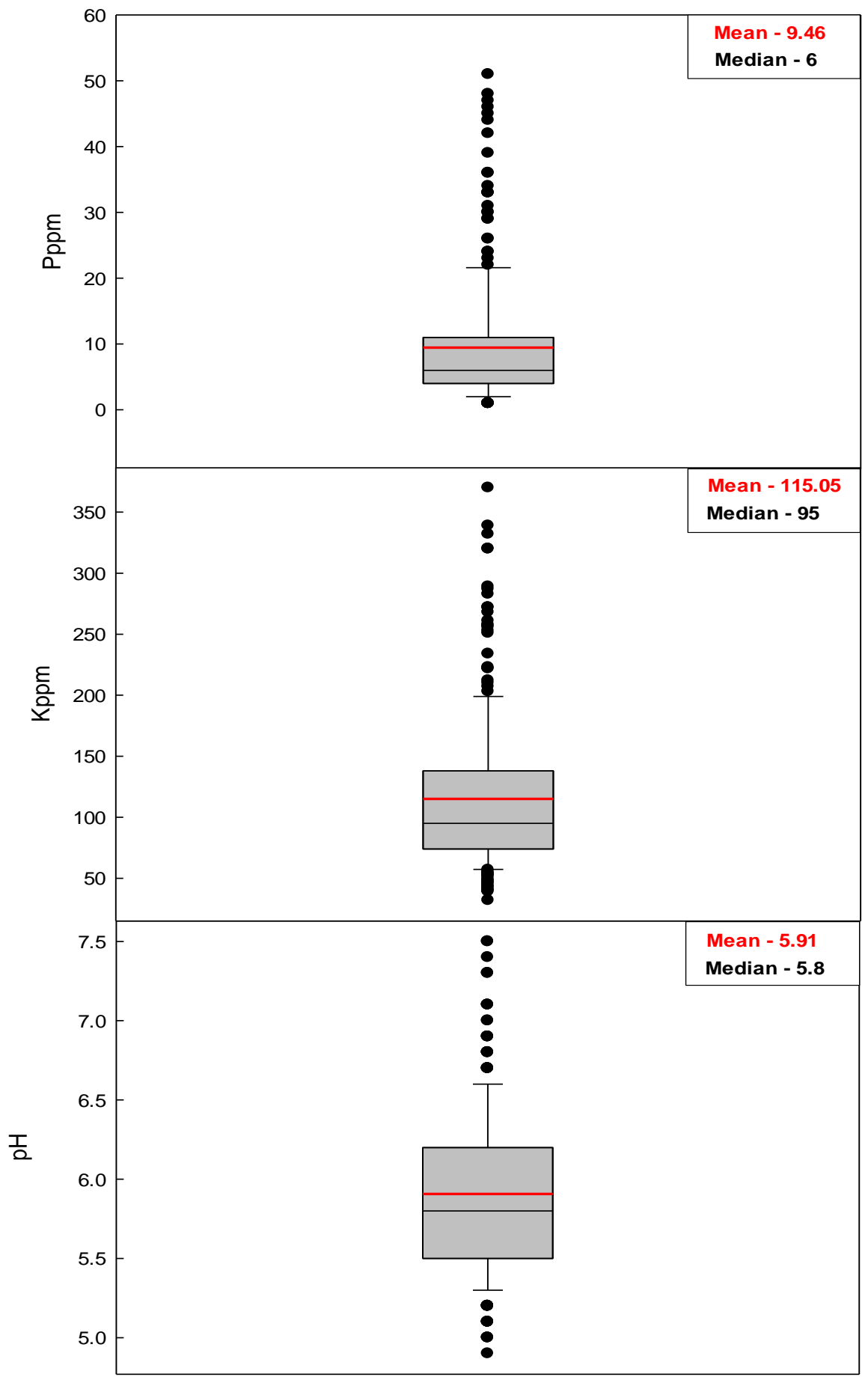

Figure 2.13. Range in soil phosphorus (Pppm), potassium (Kppm) and soil pH for all soil samples taken in the 2015-2016 pasture survey. 


\title{
Chapter III
}

\section{Seasonal Variation in Forage Nutritive Value of Common Pasture Weed Species in Missouri Pastures}

Zachary L. Trower, Craig A. Roberts, and Kevin W. Bradley,

\begin{abstract}
Weed and representative forage samples were collected from 22 mixed tall fescue and legume pastures during the 2015 and 2016 growing seasons to investigate the seasonal variation in forage quality of 15 common pasture weeds in Missouri. Sampling occurred at 14-day intervals throughout the season and began in early April or when emergence of each weed species was observed. Sampling concluded either at plant senescence or mid- to late-September. There was no significant linear relationship between increasing time and crude protein (CP) concentration or digestibility for buckhorn plantain, dandelion, sericea lespedeza, and yellow foxtail, but CP concentration and digestibility declined linearly $(\mathrm{P}<0.05)$ through the growing season for all other weed species evaluated. Most weed species also had a linear decline $(\mathrm{P}<0.05)$ in neutral detergent fiber digestibility (NDFD) and a linear increase in neutral detergent fiber (NDF) as the season progressed. When comparing pure weed samples to the representative forage from the same location, $\mathrm{CP}$ concentrations in spiny amaranth, woolly croton, annual fleabane, white snakeroot, Pennsylvania smartweed, and vervain species were not significantly different $(\mathrm{P}<0.05)$ than their representative forage samples at any sampling interval throughout the season. However, $\mathrm{CP}$ concentration of common ragweed, lanceleaf ragweed, horsenettle, and dandelion were often higher than the
\end{abstract}


representative forage sample for the majority of sampling timings throughout the season while yellow foxtail and ironweed species had significantly lower CP concentration than the representative forage samples from July 26 to August $23(\mathrm{P}<0.05)$. Additionally, digestibility of common ragweed, lanceleaf ragweed, broadleaf plantain, Pennsylvania smartweed, dandelion, and common cocklebur was greater than that of the representative forage sample for the majority of sampling periods throughout the season $(\mathrm{P}<0.05)$.

These results can be used to understand how the nutritive value of common weed species changes throughout the season and at what times specific weed species have the potential to influence the overall forage quality in mixed tall fescue and legume pastures.

\section{Introduction}

Grassland pastures and rangeland make up an estimated 214 million ha, or 29.2\%, of the total land area of the United States and approximately 2.83 million ha of land in Missouri (USDA ERS 2012). In Missouri, and throughout much of the Midwestern and mid-Atlantic United States, tall fescue (Lolium arundinacea Shreb.) is the predominant forage grass found in pastures (Glenn et al. 1981). Mixed tall fescue and legume pastures serve as the predominant source of nutrition for beef cattle in this region, sometimes colloquially referred to as the "fescue belt."

Annual, biennial, and perennial weed species are the number one pest found in pastures across the United States. It has been estimated that weed infestations in pastures result in a 2 billion dollar loss annually in the United States (Bovey 1987). Weeds compete for space, nutrients, moisture, and light that is needed for healthy forage growth, 
ultimately lowering forage yield and quality (Green et al. 2006; Rosenbaum et al. 2011). Several authors have conducted research on the forage nutritive value and palatability of common pasture weed species (Marten and Andersen 1975; Rosenbaum et al. 2011; Bosworth 1986; Bosworth 1980; Marten 1975; Marten 1987). However, most of these studies have focused on specific points in time and/or specific weeds growth stages. For example, Marten and Anderson (1975) harvested 12 common annual weeds in late-June to mid-July and compared the forage quality of these weeds to that of alfalfa harvested at the same time (Marten and Andersen 1975). Bosworth et al. (1987) collected nine coolseason weed species at the vegetative, flowering, and fruiting stages of growth. However, both of these studies were conducted as common garden studies of pure weed stands that were fertilized and not in competition with any forage.

Two of the most common weeds that invade Missouri pastures are common ragweed (Ambrosia artemisiifolia L.) and common cocklebur (Xanthium strumarium L.) (Webster 2012). Rosenbaum et al. (2011) showed that each additional increase in common ragweed and common cocklebur plants per $\mathrm{m}^{2}$ in a tall fescue pasture lowered the crude protein $(\mathrm{CP})$ content of the total harvested forage by 0.2 and $0.4 \mathrm{~g} \mathrm{~kg}^{-1}$, respectively (Rosenbaum et al. 2011). Conversely, other research has shown that common ragweed had nutrient composition and digestibility essentially equivalent to that of high quality alfalfa (Marten and Anderson 1975). Additionally, research has shown that controlling tall goldenrod [Solidago canadensis subsp. altissima (L.)] with herbicides did not reduce the overall yield or nutritive value of the total harvested biomass in mixed tall fescue and legume hayfields (Payne and Bradley 2010). These results illustrate that 
pastures are very complex systems and that nutritive values can vary greatly between weed species and growth stages.

To date, little research has been conducted that illustrates the change in forage nutritive value of common pasture weeds throughout the growing season. The objectives of this research were to examine the seasonal variation in forage nutritive values of common pasture weed species encountered in mixed tall fescue and legume pastures in Missouri, and to compare these nutritive values to that of the representative forage in that pasture at the same point in time during the season.

\section{Materials and Methods}

Weed and representative forage sample collections were conducted in conjunction with a pasture weed survey conducted during the 2015 and 2016 growing seasons at 22 locations across the state of Missouri (Table 3.1). Specific site information such as weed species, year collected, location, and soil type are presented in Table 3.1. Sampling for individual weed species began in early April or when emergence of each weed species was observed and sampling concluded either at plant senescence or the conclusion of the pasture survey, whichever came first. Sampling timing occurred at 14-day intervals, beginning in mid-April and concluding in mid-September. Weed species were selected based on prevalence in Missouri pastures or the need for additional information on the forage quality.

Weed species selected consisted of annual fleabane, Erigeron annuus L.; buckhorn plantain, Plantago major L.; common cocklebur, Xanthium strumarium L.; 
common ragweed, Ambrosia artemisiifolia L.; dandelion, Taraxacum officinale F.H. Wigg.; horsenettle, Solanum carolinense L.; ironweed species, Vernonia spp.; lanceleaf ragweed, Ambrosia bidentata Michx.; pennsylvania smartweed, Polygonum pensylvanicum L.; sericea lespedeza, Lespedeza cuneata (Dum. Cours.) G. Don; spiny amaranth, Amaranthus spinosus L.; vervain species, Verbena spp.; white snakeroot, Ageratina altissima L.; woolly croton, Croton capitatus Michx.; and yellow foxtail, Setaria pumila (Poir.) Roemer \& J.A. Schultes). Ironweed species and vervain species were grouped as such to eliminate the possibility of misidentification during early stages of growth. Ironweed species was comprised of Baldwin's ironweed (Vernonia baldwinii Torr.) and tall ironweed (Vernonia gigantea (Walter) Trel), while vervain species was comprised of white vervain (Verbena urticifolia L.) and blue vervain (Verbena hastata L.). After each survey of a given pasture, an area that best represented the composition of the forage across the whole pasture was chosen, and a $100 \mathrm{~g}$ sample of grass forage and legume species present were clipped to a height of $2.5 \mathrm{~cm}$.

After collection, weed and forage samples were stored in a freezer, freeze-dried for 14 days at $-10^{\circ} \mathrm{C}$ and then ground through an Udy Cyclone Mill (Udy Corporation, 201 Rome Court, Ft. Collins, CO 80524) to pass a 1-mm screen. Samples were analyzed using a FOSS NIRSystems 5000 Spectrophotometer (FOSS NIRSystems Inc, 8091 Wallace Rd, Eden Prairie, MN 55344) to measure crude protein (CP), neutral detergent fiber (NDF), neutral detergent fiber digestibility (NDFD) and in vitro true digestibility (IVTD) of each sample. Each sample was scanned 3 times and then spectra were averaged to produce one spectrum for each sample. In vitro true digestibility (IVTD) was determined by running a 48-h in vitro digestion in the DaisyII Incubator followed by 
washing with a neutral detergent fiber (NDF) solution in the ANKOM 200 Fiber Analyzer3 (Spanghero et al. 2003). Ruminal fluid was collected from a cannulated cow offered a forage-based diet. A Leco True Spec N analyzer4 was used to determine the total amount of nitrogen in each sample; the total $\mathrm{N}$ concentration was then multiplied by 6.25 to determine the total CP for each sample (National Research Council 1996). Optimum calibration equations (Table 3.2) were based on high coefficients of determination and low standard errors calculated during regression and cross-validation. Validated equations were used to predict CP, IVTD, NDF, and NDFD of the selected weed species and representative forage samples.

Statistical analysis. Weed species data were analyzed using the PROC REG procedure in SAS (SAS 9.4, SAS Institute Inc., 100 SAS Campus Drive, Cary, NC 27513). The regression equations were used to determine the influence of time on the seasonal variation in $\mathrm{CP}, \mathrm{NDF}, \mathrm{NDFD}$, and IVTD values of each weed species. Main effects and interactions were considered significant when $P \leq 0.05$. Years were treated as replications to strengthen regression equations.

Weed species and representative forage sample data were separated and analyzed using the PROC GLIMMIX procedure in SAS (SAS 9.4, SAS Institute Inc., 100 SAS Campus Drive, Cary, NC 27513). Years were treated as replications and species and date were considered fixed effects. Comparisons of CP and IVTD concentrations were made between weed and forage species at each collection timing to determine the difference between the means. Individual treatment differences were separated using Fisher's protected LSD at $\mathrm{P} \leq 0.05$. 


\section{Results and Discussion}

Crude protein. There was no significant linear relationship in CP concentration throughout the season for buckhorn plantain, dandelion, sericea lespedeza, and yellow foxtail (Table 3.3). All other weed species evaluated had significant negative linear relationships between $\mathrm{CP}$ concentration and time over the course of the growing season. Common ragweed had an initial CP concentration of $206 \mathrm{~g} \mathrm{~kg}^{-1}$, but CP concentration declined by $0.5 \mathrm{~g} \mathrm{~kg}^{-1}$ per day during the growing season (Table 3.3). Marten and Anderson (1975) reported that common ragweed had a CP concentration of $251 \mathrm{~g} \mathrm{~kg}^{-1}$ on a mid-July harvest date when plants were in a vegetative stage of growth, which is similar to the results reported herein. Spiny amaranth had the highest initial CP concentration of $231.3 \mathrm{~g} \mathrm{~kg}^{-1}$, and also had the highest reduction in CP per day at $1.0 \mathrm{~g} \mathrm{~kg}^{-1}$ (Table 3.3). Marten and Andersen (1975) reported that vegetative-stage redroot pigweed, a close relative of spiny amaranth, had a $\mathrm{CP}$ concentration of $250 \mathrm{~g} \mathrm{~kg}^{-1}$, which is comparable to the initial CP concentration that was observed for spiny amaranth in this research. Pennsylvania smartweed had the lowest initial CP concentration of $132.1 \mathrm{~g} \mathrm{~kg}^{-1}$ and the $\mathrm{CP}$ concentration declined by $0.5 \mathrm{~g} \mathrm{~kg}^{-1}$ per day through the season. Conversely, Marten and Anderson (1975) reported that Pennsylvania smartweed had a CP concentration of $244 \mathrm{~g} \mathrm{~kg}^{-1}$, a concentration that may be attributed to the plants being fertilized with $37 \mathrm{~kg}$ N/ha and grown without forage competition. Additionally, smartweed species commonly emerge in lower, wetter locations in pastures where fertility can be poor. This may have contributed to the lower CP concentration observed in this research.

In vitro true digestibility. As with $\mathrm{CP}$ concentration, there was no effect of sampling time on IVTD of buckhorn plantain, dandelion, sericea lespedeza, and yellow foxtail 
through the season, but digestibility for all other weed species declined linearly (Table 3.3). Ironweed species had the highest initial digestibility at $982.9 \mathrm{~g} \mathrm{~kg}^{-1}$ but also the highest daily reduction of $3.1 \mathrm{~g} \mathrm{~kg}^{-1}$ per day of growth (Table 3.3). Even though ironweed species have high levels of digestibility, it is postulated that poor palatability causes them to be avoided by cattle (Green and Martin 1998). Annual fleabane also had high initial digestibility levels $\left(953.8 \mathrm{~g} \mathrm{~kg}^{-1}\right)$ but also had a rapid rate of decline in digestibility throughout the season $\left(3 \mathrm{~g} \mathrm{~kg}^{-1} \mathrm{day}^{-1}\right)$. Common ragweed and lanceleaf ragweed had very similar initial digestibility levels of 974.2 and $974.4 \mathrm{~g} \mathrm{~kg}^{-1}$, respectively, but lanceleaf ragweed exhibited a more rapid decline in digestibility through the season than common ragweed (Table 3.3). This may be due to fact that lanceleaf ragweed emerged later and flowered sooner than common ragweed in mixed tall fescue and legume pastures in Missouri. As plants mature, digestibility decreases due to higher lignin concentration (Ball et al. 2001). This supports the findings in Table 3.3, as plants that were observed to go through there vegetative stages faster throughout the season and flower sooner had greater daily decreases in digestibility compared to weeds that had longer seasonal vegetative growth and that flower later in the season.

Neutral Detergent Fiber. Neutral detergent fiber is a forage testing technique that approximates the total cell wall constituents including hemicellulose, and is used to predict intake potential of a forage (Ball et al. 2001). The basic assumption is the lower the NDF, the higher the intake of the plant (Belyea et al. 1993). For example, a 1000 pound beef cow's estimated daily forage dry matter intake (DMI) for a forage with an NDF percent of 40 is $11.3 \mathrm{~kg}$. Dry matter intake would decrease to $7.5 \mathrm{~kg}$ if the forage 
NDF percent increased to 60, resulting in a 34 percent reduction in forage DMI (Belyea et al. 1993).

As NDF increases for the selected species in Table 3.3, the potential to reduce the overall forage intake and quality of the desirable forage species also increases. Buckhorn plantain, dandelion, and yellow foxtail did not have a significant linear relationship betwenn NDF concentration and increasing time over the course of the growing season (Table 3.3). However, NDF concentration increased linearly for all other species, indicating that there is a standard increase in NDF per day for the species in Table 3.3. Sericea lespedeza and woolly croton exhibited the highest initial NDF concentrations of 484.6 and $427 \mathrm{~g} \mathrm{~kg}^{-1}$, respectively (Table 3.3). Ironweed species and annual fleabane had the highest daily increase of NDF with 2.9 and $2.5 \mathrm{~g} \mathrm{~kg}^{-1}$, respectively (Table 3.3). Common and lanceleaf ragweed had similar initial NDF concentrations with 257.0 and $269.8 \mathrm{~g} \mathrm{~kg}^{-1}$ and similar daily increases of 1.4 and $1.8 \mathrm{~g} \mathrm{~kg}^{-1}$, respectively (Table 3.3). Vervain species and white snakeroot had high initial NDF concentrations of 312.3 and $308.3 \mathrm{~g} \mathrm{~kg}^{-1}$, respectively. Both species have low leaf-to-stem, which often results in a higher fiber percent (Ball et al. 2001). Conversely, spiny amaranth, annual fleabane, and common ragweed had lower initial NDF concentrations and were observed to have higher leaf:stem ratios initially. Seasonal observations suggest that 3 factors are responsible for high daily increases in NDF in weed species; an upright growth habit, a tough fibrous stem, and an ability to progress through growth stages to flowering in a short amount of time.

Neutral detergent fiber digestibility. Neutral detergent fiber digestibility is the measure of NDF that is digestible, so higher NDFD values are more desirable, indicating that even 
if the fiber concentration is high, there is less likelihood that the weed species will decrease overall forage quality. For example, Pennsylvania smartweed had a high initial NDF concentration of $303.4 \mathrm{~g} \mathrm{~kg}^{-1}$, but the initial NDFD value was $492.6 \mathrm{~g} \mathrm{~kg}^{-1}$, indicating that Pennsylvania smartweed had a high amount of fiber initially, but only $49 \%$ of the fiber is digestible $\left(492.6 \mathrm{~g} \mathrm{~kg}^{-1} \div 10\right)$. Conversely, ironweed species had the lowest initial NDF concentration $\left(208.8 \mathrm{~g} \mathrm{~kg}^{-1}\right)$ but the second highest initial NDFD concentration (Table 3.3). There was not a significant linear relationship between NDFD concentration and increasing time found for buckhorn plantain, dandelion, sericea lespedeza, spiny amaranth, and yellow foxtail over the season (Table 3.3). However NDFD of all other weed species declined linearly throughout the season. Common ragweed and ironweed species had the highest initial NDFD concentrations of 805.6 and $797.5 \mathrm{~g} \mathrm{~kg}^{-1}$, respectively, while Pennsylvania smartweed and woolly croton had the lowest initial NDFD concentrations (Table 3.3). Annual fleabane and ironweed species had the highest daily reductions in NDFD of 4.3 and $4.1 \mathrm{~g} \mathrm{~kg}^{-1}$, respectively (Table 3.3). Lanceleaf ragweed showed a higher daily reduction in NDFD $\left(3.4 \mathrm{~g} \mathrm{~kg}^{-1}\right)$ compared to common ragweed ( $\left.2.6 \mathrm{~g} \mathrm{~kg}^{-1}\right)$, which could be attributed to lanceleaf ragweed's shorter life cycle and stiff, fibrous stem.

Weed and forage comparisons. Crude protein $(\mathrm{CP})$ concentrations in spiny amaranth, woolly croton, annual fleabane, white snakeroot, Pennsylvania smartweed, and vervain species were not significantly different than their representative forage samples at any sampling interval throughout the season (Table 3.4). CP concentration of common ragweed was 4.8 to $81.6 \mathrm{~g} \mathrm{~kg}^{-1}$ higher than the representative forage samples for 7 out of the 11 sampling timings. Marten and Andersen (1975) showed that common ragweed 
had a CP concentration of $260 \mathrm{~g} \mathrm{~kg}^{-1}$ when averaged over 3 years at a late-June to midJuly collection time compared to oats with a CP concentration of $190 \mathrm{~g} \mathrm{~kg}^{-1}$. The CP concentration for the oats was higher than the average $\mathrm{CP}$ concentration of the mixed tall fescue and legume samples collected in this research (average $137 \mathrm{~g} \mathrm{~kg}^{-1}$, data not shown). Horsenettle had higher $\mathrm{CP}$ concentration than the representative forage samples for 7 out of the 9 sampling timings, with differences ranging from 44.2 to $109.3 \mathrm{~g} \mathrm{~kg}^{-1}$. Conversely, yellow foxtail had significantly lower CP concentration than the representative forage samples from July 26 to August 23, and these differences ranged from 37 to $42.9 \mathrm{~g} \mathrm{~kg}^{-1}$. Marten and Anderson (1975) also reported that yellow foxtail had a significantly lower $\mathrm{CP}$ concentration than alfalfa, but few studies have compared the nutritional concentration of yellow foxtail with that of a mixed tall fescue and legume pasture (Marten and Anderson 1975). This is an important finding in that many pastures in Missouri become dominated by yellow foxtail in the late summer/early fall (K. Bradley, personal communication). Similarly, ironweed species had a lower CP concentration than the representative forage samples from July 26 to August 23 . The results in Table 3.4 can be used to determine if specific pasture weeds have the potential to raise or lower the $\mathrm{CP}$ concentration of the overall forage and also provides information as to when these changes are most likely to occur throughout the season.

Digestibility of white snakeroot and yellow foxtail was not different than the representative forage samples at any sampling interval throughout the season (Table 3.5). Common ragweed had higher IVTD for 9 out of the 11 collection timings, ranging from 210 to $58 \mathrm{~g} \mathrm{~kg}^{-1}$ higher than the representative forage samples from May 3 to August 23, but had a significantly lower IVTD value than the representative forage samples on 
September 20. Marten and Anderson (1975) reported that common ragweed digestibility did not differ significantly from alfalfa, while Rosenbaum et al. (2011) showed that increasing common ragweed densities significantly decreased tall fescue digestibility (Marten and Anderson 1975; Rosenbaum et al. 2011). Dandelion was higher in digestibility for all 12 collection timings than the representative forage samples, with differences ranging from 70 to $218 \mathrm{~g} \mathrm{~kg}^{-1}$ higher than representative forage samples (Table 3.5). Marten et al. (1987) also reported that the digestibility of dandelion across 2 years and 2 samplings at three growth stages was either higher or similar to alfalfa in the respective stages of early-bud, late-bud, mid-bloom, or full-bloom (Marten et al. 1987). Ironweed species were significantly higher in IVTD than the representative forage samples for 4 out of 9 sampling timings, but significantly lower than the representative forage sample for the August 23 collection date. By this time, ironweed had developed tough, fibrous stems and lost most of its leaf biomass, which resulted in lower digestibility due to increased lignin concentration. The results in Table 3.5 can be used to determine if specific pasture weeds have the potential to positively or negatively impact the digestibility of the overall pasture forage and if so, provides information as to when this is most like to occur during the growing season.

Many weed species that commonly invade Missouri pastures have their highest nutritional value earlier in the season at emergence, but most of these species have a linear decline in CP, IVTD, and NDFD as the season progresses. Additionally, many weed species have higher $\mathrm{CP}$ concentration and digestibility than representative forage samples taken from mixed tall fescue and legume pastures at the same time of the season. For example, common ragweed was higher in $\mathrm{CP}$ concentration than the representative 
forage samples for 7 out of the 11 sampling intervals, and had significantly higher IVTD concentration than their representative forage samples for 9 out of the 11 timings. Conversely, yellow foxtail's CP concentration was significantly lower than the representative forage sample for 3 of the 5 sampling timings in the late summer/early fall, but did not show any significant differences in IVTD concentration at any timing when compared to the representative forage samples. These examples illustrate how 2 very common, high density weed species can potentially increase or decrease certain aspects of forage quality, or may not have any effect on specific aspects of forage quality such as digestibility and $\mathrm{CP}$.

These results will help practitioners to understand how the nutritive value of common weed species changes throughout the season, and at what times during the season specific weed species has the potential to positively or negatively influence the overall forage quality of mixed tall fescue and legume pastures that are common throughout much of the eastern half of the United States. 


\section{Literature Cited}

Ball DM, Collins M, Lacefield GD, Martin NP, Mertens DA, Olson KE, Putnam DH, Undersander DJ, Wolf MW (2001) Understanding forage quality. American Farm Bureau Federation Publication 1-01, Park Ridge, Illinois

Belyea RL, Steevens BJ, Garner GB, Whittier JC, Sewell HB (1993) Using NDF and ADF To Balance Diets. University of Missouri Extension G3150.

Bosworth SC, Hoveland CS, Buchanan GA (1986) Forage quality of selected cool-season weed species. Weed Sci 34:150-154

Bosworth SC, Hoveland CS, Buchanan GA, Anthony WB (1980) Forage Quality of selected Warm-Season Weed Species. Agron J 72:1050-1054

Bovey RW (1987) Weed control problems, Approaches, and Opportunities in Rangeland. Weed Sci 3:57-91

Glenn S, Glenn BP, Rieck CE, Ely DG, Bush LP (1981) Chemical quality, in vitro cellulose digestion, and yield of tall fescue forage affected by mefluidide. J Agric Food Chem 29:1158-1161

Green JD, Martin JR (1998) Weed Management in Grass Pastures, Hayfields, and Fencerows. University of Kentucky Extension Service AGR-112.

Marten GC, Andersen RN (1975) Forage nutritive value and palatability of 12 common annual weeds. Crop Sci 15:821-827

Marten GC, Sheaffer CC, Wyse DL (1987) Forage nutritive value and palatability of perennial weeds. Agron J 79:980-986

National Research Council (1996) Nutrient Requirements of Beef Cattle, 7th rev. ed. Washington, DC: Nat Acad Press. 16 p.

Payne KK, Bradley KW (2010) Herbicidal control of tall goldenrod in tall fescue hayfields. Forage and Grazinglands DOI: 10.1094/FG-2010-0426-01-RS

Rosenbaum KK, Bradley KW, Roberts CA (2011) Influence of increasing common ragweed (Ambrosia artemisiifolia) or common cocklebur (Xanthium strumarium) densities on forage nutritive value and yield in tall fescue pastures and hay fields. Weed Technol 25:222-229

Spanghero M, Boccalon S, Gracco L, Gruber L (2003) NDF digestibility of hays measured in situ and in vitro. Anim Feed Sci Technol 104:201-208.

Webster TM (2012) Weed survey, grass crops subsection. Pages 267-288 in Proceedings of the $65^{\text {th }}$ Annual South Weed Science Society. Charleston, South Carolina 
[USDA] US Deparment of Agriculture Economic Research Service (2012) United States State Fact Sheet 2012. Washington, DC: U.S. Department of Agriculture 
Table 3.1. Site characteristics for collection locations in 2015 and $2016 .^{\mathrm{a}}$

Soil properties

\begin{tabular}{|c|c|c|c|c|c|c|c|}
\hline \multirow[b]{2}{*}{ Common name } & \multirow[b]{2}{*}{ Year } & \multirow[b]{2}{*}{$\begin{array}{l}\text { Collection } \\
\text { location }\end{array}$} & \multirow[b]{2}{*}{ GPS coordinate } & \multicolumn{4}{|c|}{ Soil properties } \\
\hline & & & & Texture & $\% \mathrm{OM}$ & $\mathrm{pH}$ & CEC \\
\hline \multirow[t]{2}{*}{ Annual fleabane } & 2015 & Dade2 & $37.47158,-93.85844$ & Goss silt loam & 6.8 & 6.2 & 15.2 \\
\hline & 2016 & Audrain5 & $39.38357,-91.42166$ & Crider silt loam & 2.2 & 6.1 & 10.6 \\
\hline \multirow[t]{2}{*}{ Buckhorn plantain } & 2015 & Howell3 & $37.39518,-92.33871$ & Viraton silt loam & 3.2 & 6.6 & 8.7 \\
\hline & 2016 & Audrain4 & $39.36586,-91.87598$ & Mexico silt loam & 3.5 & 5.8 & 14.6 \\
\hline \multirow[t]{2}{*}{ Common cocklebur } & 2015 & Howard2 & $39.03919,-92.81324$ & Menfro silt loam & 4.1 & 5.4 & 20.3 \\
\hline & 2016 & Boone1 & $38.90488,-92.26306$ & Armstrong loam & 3.9 & 6.8 & 14.0 \\
\hline \multirow[t]{2}{*}{ Common ragweed } & 2015 & Howard1 & $39.28156,-92.69848$ & Grundy silt loam & 3.3 & 5.4 & 14.2 \\
\hline & 2016 & Crawford 2 & $38.18060,-91.23511$ & Gravois silt loam & 1.7 & 6.6 & 7.3 \\
\hline \multirow[t]{2}{*}{ Dandelion } & 2015 & Howard2 & $39.03919,-92.81324$ & Menfro silt loam & 4.1 & 5.4 & 20.3 \\
\hline & 2016 & Boone1 & $38.90488,-92.26306$ & Armstrong loam & 3.9 & 6.8 & 14.0 \\
\hline \multirow[t]{2}{*}{ Horsenettle } & 2015 & Cooper3 & $38.81666,-92.57087$ & Leslie silt loam & 3.5 & 5.2 & 12.5 \\
\hline & 2016 & Crawford2 & $38.18060,-91.23511$ & Gravois silt loam & 1.7 & 6.6 & 7.3 \\
\hline \multirow[t]{2}{*}{ Ironweed spp. } & 2015 & Moniteau1 & $38.77083,-92.53566$ & Bluelick silt loam & 3.8 & 6.1 & 13 \\
\hline & 2016 & Texas 2 & $37.25777,-91.74920$ & Viburnum silt loam & 3.6 & 5.0 & 7.7 \\
\hline \multirow[t]{2}{*}{ Lanceleaf ragweed } & 2015 & Howard1 & $39.28156,-92.69848$ & Grundy silt loam & 3.3 & 5.4 & 14.2 \\
\hline & 2016 & Howell4 & $36.88707,-91.80091$ & Taherhill silt loam & 3.5 & 5.8 & 6.9 \\
\hline Pennsylvania smartweed & 2015 & Howard1 & $39.28156,-92.69848$ & Grundy silt loam & 3.3 & 5.4 & 14.2 \\
\hline
\end{tabular}




\begin{tabular}{|c|c|c|c|c|c|c|c|}
\hline & 2016 & Monroe3 & $39.53994,-91.76583$ & Armstrong loam & 3.0 & 6.3 & 11.0 \\
\hline \multirow[t]{2}{*}{ Sericea lespedeza } & 2015 & Cedar1 & $37.83828,-94.05377$ & Barco-sylvania complex & 3.2 & 5.4 & 9.8 \\
\hline & 2016 & Crawford2 & $38.18060,-91.23511$ & Gravois silt loam & 1.7 & 6.6 & 7.3 \\
\hline \multirow[t]{2}{*}{ Spiny amaranth } & 2015 & Cooper2 & $38.85299,-92.47108$ & Hartville silt loam & 3.6 & 6.5 & 16 \\
\hline & 2016 & Monroe1 & $39.54646,-92.17271$ & Mexico silt loam & 3.7 & 5.6 & 16.5 \\
\hline \multirow[t]{2}{*}{ Vervain spp. } & 2015 & Cooper3 & $38.81666,-92.57087$ & Leslie silt loam & 3.5 & 5.2 & 12.5 \\
\hline & 2016 & Howell4 & $36.88707,-91.80091$ & Taherhill silt loam & 3.5 & 5.8 & 6.9 \\
\hline \multirow[t]{2}{*}{ White snakeroot } & 2015 & Cooper3 & $38.81666,-92.57087$ & Leslie silt loam & 3.5 & 5.2 & 12.5 \\
\hline & 2016 & Audrain5 & $39.38357,-91.42166$ & Crider silt loam & 2.2 & 6.1 & 10.6 \\
\hline \multirow[t]{2}{*}{ Woolly croton } & 2015 & Howell3 & $37.39518,-92.33871$ & Viraton silt loam & 3.2 & 6.6 & 8.7 \\
\hline & 2016 & Howell4 & $36.88707,-91.80091$ & Taherhill silt loam & 3.5 & 5.8 & 6.9 \\
\hline \multirow[t]{2}{*}{ Yellow foxtail } & 2015 & Moniteau1 & $38.77083,-92.53566$ & Bluelick silt loam & 3.8 & 6.1 & 13 \\
\hline & 2016 & Crawford2 & $38.18060,-91.23511$ & Gravois silt loam & 1.7 & 6.6 & 7.3 \\
\hline
\end{tabular}


Table 3.2. Near-infrared reflectance spectroscopy calibration and validation statistics for CP, NDF, IVTD, and NDFD for 20152016 data.

\begin{tabular}{lcccccc}
\hline Constituent & $\mathrm{n}$ & $\mathrm{R}^{2}$ & Mean & SEC & SECV \\
\hline & & & & $\mathrm{g} \mathrm{kg}^{-1} \mathrm{dm}$ & \\
$\mathrm{CP}^{\mathrm{a}}$ & 130 & .95 & 132.4 & 8.2 & 9.5 & 0.93 \\
$\mathrm{NDF}$ & 134 & .95 & 433.8 & 27.9 & 32.3 & 0.94 \\
IVTD & 136 & .92 & 783.8 & 32.4 & 39.2 & 0.88 \\
NDFD & 137 & .87 & 519.3 & 66.2 & 82.8 & 0.80 \\
\hline
\end{tabular}

a Abbreviations: CP, crude protein; NDF, Neutral Detergent Fiber; IVTD, In Vitro True Digestibility; NDFD, Neutral Detergent Fiber Digestibility

$\mathrm{SEC}=$ Standard Error of calibration

$\mathrm{SECV}=$ Standard Error of cross-validation in modified partial least squares regression

$\mathrm{R}^{2}=$ Coefficient of determination for calibration

@ $1-\mathrm{VR}=1$ minus the variance ratio calculated in cross-validation during modified partial least squares regression 
Table 3.3. Daily influence on nutritional values of selected weed species from emergence to maturity. ${ }^{\mathrm{a}}$

\begin{tabular}{|c|c|c|c|c|c|c|c|c|c|c|c|c|}
\hline \multirow[b]{2}{*}{$\begin{array}{l}\text { Weed } \\
\text { species }\end{array}$} & \multicolumn{3}{|c|}{$\mathrm{CP}$} & \multicolumn{3}{|c|}{ IVTD } & \multicolumn{3}{|c|}{$\mathrm{NDF}$} & \multicolumn{3}{|c|}{ NDFD } \\
\hline & P-Value & Equation $^{\mathrm{b}}$ & $\mathrm{R} 2$ & P-Value & Equation & $\mathrm{R} 2$ & P-Value & Equation & $\mathrm{R} 2$ & P-Value & Equation & $\mathrm{R} 2$ \\
\hline AMASP & 0.0049 & $Y=-1.0 x+231.3$ & 0.48 & 0.0188 & $Y=-1.6 x+947.3$ & 0.35 & 0.0118 & $Y=1.4 x+239.8$ & 0.40 & 0.0852 & --- & ---- \\
\hline AMBBI & $<.0001$ & $Y=-.4 x+170.4$ & 0.63 & $<.0001$ & $Y=-2.6 x+974.4$ & 0.97 & $<.0001$ & $Y=1.8 x+269.7$ & 0.90 & $<.0001$ & $Y=-3.4 x+735.4$ & 0.90 \\
\hline AMBEL & 0.0001 & $Y=-.5 x+206$ & 0.48 & $<.0001$ & $Y=-1.9 x+974.2$ & 0.90 & $<.0001$ & $Y=1.4 x+257.0$ & 0.81 & $<.0001$ & $Y=-2.6 x+805.6$ & 0.89 \\
\hline CVNCP & 0.0002 & $Y=-.6 x+183.6$ & 0.55 & $<.0001$ & $Y=-1.5 x+789.7$ & 0.73 & $<.0001$ & $Y=1.2 x+427.0$ & 0.71 & $<.0001$ & $Y=-2.0 x+520.5$ & 0.68 \\
\hline ERIAN & 0.0004 & $Y=-.6 x+150.5$ & 0.58 & $<.0001$ & $Y=-3.0 x+953.8$ & 0.78 & $<.0001$ & $\mathrm{Y}=2.5 \mathrm{x}+238.2$ & 0.72 & $<.0001$ & $Y=-4.3 x+766.9$ & 0.83 \\
\hline EUPRU & 0.0008 & $Y=-.4 x+164.1$ & 0.38 & $<.0001$ & $Y=-1.6 x+869.7$ & 0.70 & $<.0001$ & $Y=1.3 x+308.3$ & 0.62 & $<.0001$ & $Y=-2.6 x+645.9$ & 0.71 \\
\hline LESSL & 0.528 & --- & ---- & 0.4795 & --- & ---- & 0.0496 & $Y=.6 x+484.6$ & 0.17 & 0.7751 & --- & --- \\
\hline PLALA & 0.2604 & ---- & ---- & 0.263 & --- & ---- & 0.1778 & ---- & ---- & 0.8644 & --- & ---- \\
\hline POLPY & 0.0097 & $Y=-.5 x+132.1$ & 0.28 & $<.0001$ & $Y=-1.5 x+888.2$ & 0.87 & $<.0001$ & $\mathrm{Y}=1.0 \mathrm{x}+303.4$ & 0.70 & 0.0006 & $Y=-1.7 x+492.6$ & 0.46 \\
\hline SETLU & 0.1216 & --- & ---- & 0.1309 & --- & ---- & 0.305 & --- & ---- & 0.3292 & --- & --- \\
\hline SOLCA & 0.0215 & $\mathrm{Y}=-.2 \mathrm{x}+198.2$ & 0.22 & 0.0018 & $\mathrm{Y}=-.7 \mathrm{x}+818.2$ & 0.39 & 0.0473 & $Y=.4 x+379.6$ & 0.16 & 0.0004 & $\mathrm{Y}=-1.2 \mathrm{x}+542.2$ & 0.48 \\
\hline TAROF & 0.1858 & --- & ---- & 0.5203 & --- & --- & 0.6882 & --- & ---- & 0.21 & --- & --- \\
\hline VEBSP & 0.0328 & $Y=-.3 x+139$ & 0.18 & 0.004 & $Y=-1.3 x+859.0$ & 0.33 & 0.0045 & $\mathrm{Y}=.9 \mathrm{x}+312.3$ & 0.32 & 0.0003 & $Y=-2.2 x+594.8$ & 0.48 \\
\hline VENSP & $<.0001$ & $Y=-.8 x+183.7$ & 0.77 & $<.0001$ & $Y=-3.1 x+982.9$ & 0.88 & $<.0001$ & $Y=2.9 x+208.8$ & 0.91 & $<.0001$ & $Y=-4.1 x+797.5$ & 0.83 \\
\hline XANST & 0.0180 & $Y=-.6 x+199.3$ & 0.29 & $<.0001$ & $Y=-1.4 x+939.1$ & 0.68 & 0.0001 & $Y=1.3 x+258.6$ & 0.65 & 0.0003 & $Y=-2.0 x+719.5$ & 0.59 \\
\hline
\end{tabular}


a Abbreviations: CP, Crude Protein; IVTD, In-Vitro True Digestibility; NDF, Neutral Detergent Fiber; NDFD, Neutral Detergent Fiber Digestibility; AMASP, spiny amaranth; AMBBI, lanceleaf ragweed; AMBEL, common ragweed; CVNCP, woolly croton; ERIAN, annual fleabane; EUPRU, white snakeroot; LESSL, sericea lespedeza; PLALA, buckhorn plantain; POLPY, Pennsylvania smartweed; SETLU, yellow foxtail; SOLCA, horsenettle; TAROF, dandelion; VEBSP, Vervain spp.; VENSP, Ironweed spp.; XANST, common cocklebur

${ }^{\mathrm{b}}$ All equations are measured as $\mathrm{g} \mathrm{kg}^{-1} \mathrm{dm}$ 
Table 3.4. Comparisons in crude protein content between selected weed species and the respective pure forage sample at each collection timing throughout the season $^{\mathrm{a}}$

\begin{tabular}{|c|c|c|c|c|c|c|c|c|c|c|c|c|}
\hline \multirow[b]{2}{*}{$\begin{array}{l}\text { Weed } \\
\text { species }\end{array}$} & \multicolumn{12}{|c|}{ Average Collection Date } \\
\hline & $4 / 19$ & $5 / 3$ & $5 / 17$ & $5 / 31$ & $6 / 14$ & $6 / 28$ & $7 / 12$ & $7 / 26$ & $8 / 9$ & $8 / 23$ & $9 / 6$ & $9 / 20$ \\
\hline \multicolumn{13}{|c|}{ 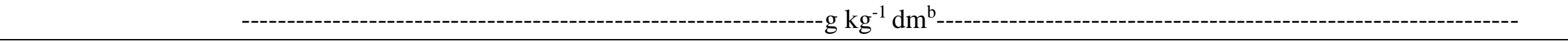 } \\
\hline AMASP & ---- & ---- & ---- & ---- & ---- & ---- & 44.6 & -1.9 & 27.4 & -3.2 & 20.3 & -11.0 \\
\hline AMBBI & ---- & --- & ---- & $62.4^{*}$ & $35.0^{*}$ & $30.9 *$ & 14.3 & $27.5^{*}$ & 7.9 & 11.3 & -8.5 & 0.5 \\
\hline AMBEL & ---- & 20.9 & $51.1^{*}$ & $81.6^{*}$ & $69.6^{*}$ & $66.9 *$ & $59.0 *$ & $41.7 *$ & 16.5 & 15.0 & -1.6 & $4.8^{*}$ \\
\hline CVNCP & ---- & ---- & ---- & 41.0 & 7.5 & -25.9 & -21.0 & -16.9 & 3.5 & -14.6 & -30.7 & -16.2 \\
\hline ERIAN & -21.7 & -0.6 & 20.9 & 3.0 & -48.3 & -48.1 & ---- & --- & ---- & ---- & ---- & --- \\
\hline EUPRU & ---- & 38.3 & 21.3 & 23.4 & 11.8 & 22.0 & 46.1 & -29.3 & 19.5 & -1.5 & -14.0 & -34.0 \\
\hline LESSL & ---- & ---- & ---- & $53.2 *$ & 14.3 & 10.2 & -19.0 & -23.6 & -33.6 & -25.2 & -7.3 & 12.0 \\
\hline PLALA & ---- & 38.8 & 44.2 & $61.3^{*}$ & 17.3 & 30.8 & 21.6 & 24.2 & 19.7 & 20.2 & -3.6 & 2.5 \\
\hline POLPY & ---- & ---- & 33.8 & 4.2 & -50.8 & 3.3 & -31.0 & -31.5 & -51.3 & -45.7 & -27.2 & ---- \\
\hline SETLU & ---- & ---- & ---- & ---- & ---- & ---- & ---- & $-42.9^{*}$ & $-38.3^{*}$ & $-37.0 *$ & -29.3 & -26.5 \\
\hline SOLCA & ---- & ---- & ---- & $109.3 * *$ & $95.3 * *$ & $97.6^{* *}$ & $95.1 * *$ & 28.7 & $44.2 *$ & $49.8 *$ & $68.1^{*}$ & 28.4 \\
\hline TAROF & 6.9 & 47.6 & $57.6^{*}$ & 34.7 & 3.7 & 18.8 & $85.2 *$ & 26.9 & $78.4^{*}$ & 47.2 & $89.7 *$ & 44.3 \\
\hline VEBSP & ---- & 13.1 & 13.5 & 30.4 & 23.2 & 8.6 & -2.9 & -27.1 & -10.4 & -21.8 & ---- & ---- \\
\hline VENSP & ---- & $46.1 *$ & 8.4 & 26.0 & 17.0 & -2.1 & -23.3 & $-52.2^{*}$ & $-40.4^{*}$ & $-47.8^{*}$ & ---- & ---- \\
\hline XANST & ---- & ---- & ---- & ---- & ---- & $63.6^{*}$ & 39.1 & $28.1 *$ & 20.2 & 3.6 & -11.8 & -13.9 \\
\hline
\end{tabular}


a Abbreviations: AMASP, spiny amaranth; AMBBI, lanceleaf ragweed; AMBEL, common ragweed; CVNCP, woolly croton; ERIAN, annual fleabane; EUPRU, white snakeroot; LESSL, sericea lespedeza; PLALA, buckhorn plantain; POLPY, Pennsylvania smartweed; SETLU, yellow foxtail; SOLCA, horsenettle; TAROF, dandelion; VEBSP, Vervain spp.; VENSP, Ironweed spp.; XANST, common cocklebur

${ }^{\mathrm{b}}$ Calculation of the difference in crude protein of the selected weed species and the corresponding representative forage sample. Values shown are the product of the crude protein content of the selected weed species minus the crude protein content of the respective forage sample taken at the same collection time.

$* \mathrm{P} \leq 0.05$

$* * \mathrm{P} \leq 0.001$ 
Table 3.5. Comparisons in in vitro true digestibility content between selected weed species and the respective pure forage sample at each collection timing throughout the season ${ }^{\mathrm{a}}$

\begin{tabular}{|c|c|c|c|c|c|c|c|c|c|c|c|c|}
\hline \multirow{2}{*}{$\begin{array}{l}\text { Weed } \\
\text { Species }^{\text {b }}\end{array}$} & \multicolumn{12}{|c|}{ Average Collection Date } \\
\hline & $4 / 19$ & $5 / 3$ & $5 / 17$ & $5 / 31$ & $6 / 14$ & $6 / 28$ & $7 / 12$ & $7 / 26$ & $8 / 9$ & $8 / 23$ & $9 / 6$ & $9 / 20$ \\
\hline & & & & 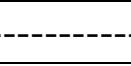 & 2 & 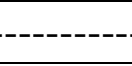 & $\mathrm{kg}^{-1} \mathrm{dm}-$ & 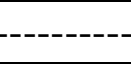 & ------ & 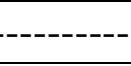 & ------- & -- \\
\hline AMASP & ---- & ---- & ---- & ---- & ---- & ---- & $122 *$ & 77 & $131 *$ & 38 & 65 & 58 \\
\hline AMBBI & ---- & ---- & ---- & $196 * *$ & $168 * *$ & $83 *$ & $86^{*}$ & $77 *$ & 35 & 12 & -37 & $-98 *$ \\
\hline AMBEL & ---- & $107 *$ & $157 * *$ & $210 * *$ & $226 * *$ & $153 * *$ & $138 * *$ & $119 *$ & $62 *$ & $58 *$ & -5 & $-65 *$ \\
\hline CVNCP & ---- & ---- & ---- & 12 & -3 & -100 & -95 & -62 & -10 & -102 & -98 & $-127 *$ \\
\hline ERIAN & 85 & $167 *$ & $138^{*}$ & 22 & -36 & -61 & ---- & ---- & ---- & ---- & ---- & ---- \\
\hline EUPRU & ---- & 86 & 88 & 75 & 92 & 90 & 83 & -35 & 42 & -54 & -65 & -104 \\
\hline LESSL & ---- & ---- & ---- & 14 & 14 & -58 & $-89 *$ & -79 & $-126^{*}$ & $-107 *$ & $-117 *$ & 18 \\
\hline PLALA & ---- & $125^{*}$ & $111^{*}$ & $140 *$ & 89 & $102 *$ & 77 & 98 & $129 *$ & $101 *$ & 71 & $119 *$ \\
\hline POLPY & ---- & ---- & $115^{*}$ & $164 *$ & $85^{*}$ & $86^{*}$ & $78 *$ & 57 & 12 & -7 & 17 & ---- \\
\hline SETLU & ---- & ---- & ---- & ---- & ---- & ---- & ---- & 64 & 79 & -0.3 & -5 & 17 \\
\hline SOLCA & ---- & ---- & ---- & $149 *$ & $161^{*}$ & $153^{*}$ & $143^{*}$ & 29 & -4 & -38 & 58 & 6 \\
\hline TAROF & $70^{*}$ & $104 *$ & $155^{* *}$ & $183 * *$ & $166^{* *}$ & $172 * *$ & $218 * *$ & $176^{* *}$ & $195 * *$ & $154 * *$ & $204 * *$ & $196 * *$ \\
\hline VEBSP & ---- & 72 & 129 & 108 & $151 *$ & 97 & 85 & -55 & -29 & -27 & ---- & ---- \\
\hline VENSP & ---- & $88^{*}$ & $154^{*}$ & $188^{*}$ & $153^{*}$ & 75 & -12 & -65 & -78 & $-86^{*}$ & ---- & ---- \\
\hline XANST & ---- & ---- & ---- & ---- & ---- & $128 *$ & $160 * *$ & $129 *$ & $122 *$ & $74 *$ & 60 & -34 \\
\hline
\end{tabular}


a Abbreviations: AMASP, spiny amaranth; AMBBI, lanceleaf ragweed; AMBEL, common ragweed; CVNCP, woolly croton; ERIAN, annual fleabane; EUPRU, white snakeroot; LESSL, sericea lespedeza; PLALA, buckhorn plantain; POLPY, Pennsylvania smartweed; SETLU, yellow foxtail; SOLCA, horsenettle; TAROF, dandelion; VEBSP, Vervain spp.; VENSP, Ironweed spp.; XANST, common cocklebur

${ }^{\mathrm{b}}$ Calculation of the difference in in vitro true digestibility of the selected weed species and the corresponding representative forage sample. Values shown are the product of the in vitro true digestibility content of the selected weed species minus the in vitro true digestibility content of the respective forage sample taken at the same collection time.

$* \mathrm{P} \leq 0.05$

$* * \mathrm{P} \leq 0.001$ 